\title{
Assessment of Commercially Important Small Pelagic Fishes in Davao Gulf CY 2004-2013
}

\author{
Jose A. Villanueva ${ }^{1, *}$ \\ ${ }^{1}$ Project Leader, National Stock Assessment Program \\ Bureau of Fisheries and Aquatic Resources XI - Ramon Magsaysay Ave., Davao City 8000
}

\section{A B S T R A C T}

Davao Gulf houses diverse marine ecosystems that support the fisheries activities of the entire Region XI. A study through the National Stock Assessment Program from 2004-2013 was conducted to provide baseline information on the stock condition and the level of exploitation of the commercially important small pelagic fishes in Davao Gulf.

The results showed that commercial fishing contributes to about $88 \%$ of the annual average landed catch in the region. Ring net (in payao or free-school) and bag net are the only commercial types of fishing gears operating in Davao Gulf with average production per year of 3,069.62 MT, 199.25 MT, 122.21 MT respectively.

Moreover, RNp is the major gear catching Selar crumenopthalmus which is $32 \%$ of the total landed catch followed by Decapterus macarellus at $16 \%$. Similarly, Mene maculata dominated the catch of RNf by $41 \%$ while most catch of BN is composed of Auxis rochei, Rastrelliger faughni and D. tabl. Species composition data indicated the bulk catch of these commercial gears is small pelagic fishes. However, the average CPUE of these gears showed a decreasing trend. The most evident decline occurred in 2013 with a drop of almost $70 \%$ in the CPUE of BN. Heavy fishing pressure is manifested since the annual harvest and the relative abundance of the small pelagic fishes generally decreased.

Likewise, $\mathrm{L}_{50}$ declined in which smaller sizes of fish are being caught as commercial gears are exploiting the juveniles. Most of the commercial fish catch has not attained maturity. The length frequency data also showed that E-values of these small pelagic fishes range from 0.51-0.86/year, an indication of exploitation above the optimum level. Consequently, the potential yield estimates already surpassed the allowable catch limit and fishing effort in both Schaefer and Fox models.

The study suggests that Davao Gulf is in the state of over exploitation due to intensified fishing operations. This calls for intervention and policy implementation to conserve and manage the fishery resources in Davao Gulf.

${ }^{\star}$ E-mail address: javnsap@yahoo.com

Received: 5 February 2017

Accepted: 20 July 2017
Keywords: stock assessment, NSAP, Davao Gulf, small pelagic fishes, ring net, bag net

\section{IN T RODUCTION}

$\mathbf{T}$ he Republic Act 8550 known as the "New Philippine Fisheries Code of 1998", in its implementing rules and regulations of Chapter II, rule 7.1 states that the determination of Maximum Sustainable Yield (MSY) and Total Allowable Catch (TAC) is within three years and three years thereafter. Through continuous stock assessment studies, an estimate of the MSY and TAC of major fisheries includes but not limited to large pelagic, reef, and demersal fisheries, for the entire Philippines and for each major fishing area.

Moreover, the National Stock Assessment Program (NSAP) at the regional level has to take the challenge to implement this mandate. The data gathered determined the MSY, TAC, and the biological aspects of fishes dominant in the fishing ground. The implementation of catch ceiling and the establishment of a closed season through Fisheries Administrative Ordinances (FAO) is based on scientific studies of fish stock assessment and other related research which serve as the best available evidence in making policy decisions and or in the legal court's decision making.

Davao Gulf encompasses multiple fishing activities, composed of commercial and municipal fisheries. It involves thousands of full-time fisher folks, a part- or full-time labor forces who are directly dependent on commercial capture fisheries as means of their livelihood and economic sources. The gulf's fishery is the livelihood for coastal inhabitants. The shared fish stock resources among the provinces and the cities of Davao are also the major sources of food protein in Region $\mathrm{XI}$ and the nearby regions. The small pelagic fishery in Davao Gulf is important not only as a source of protein and livelihood for the community but also for the benefit of the higher trophic level of the food web in the marine ecosystem. 
Similar studies were also conducted in Davao Gulf from 1983 to 1987 regarding the growth parameter estimates of species Selar crumenophthalmus (Bloch 1973), big-eyed scads or known as "matangbaka/matambaka" in local name. Gonzales (1991) and Gayanilo et. al. (1991) obtained the parameter estimates. The length infinity $\left(\mathrm{L}_{\infty}\right)$ was about $28.6 \mathrm{~cm}$ from 1983 to 1987 data; the growth curvature (k) was around 1 to 2 year $^{-1}$ and the total mortality $(\mathrm{Z})$ was about 8.3 year $^{-1}$ using the length converted catch curve. The recruitment pattern analysis showed two pulses per year.

The objectives of this study were to determine the size, species compositions and the relative abundance of small pelagic fishes caught by commercial fishing gears and establish CPUE trends of these gears. Also, to illustrate the exploitation level and provide estimates on the maximum potential yield of Davao Gulf to subsequently recommend management options towards sustainable fishing.

This study was limited to the commercially important small pelagic species found in Davao Gulf. The data for large pelagics and the demersal fish species are excluded from this study.

The importance of this study is to impart knowledge and provide baseline information to fishery policy makers, government agencies specifically to BFAR, the non-government organizations (NGOs), or any interested parties who would like to know the state of the commercially important small pelagic species and their present stock condition in Davao Gulf. The study is a basis for future reference in coastal or marine fisheries management for the conservation and protection of the fishing ground.

\section{M E T H O D O L G Y}

\section{Fishing Ground}

Davao Gulf is located in the Southeastern part of Mindanao. It lies approximately between $6^{\circ} 7^{\prime}$ and $7^{\circ} 21.5^{\prime}$ North latitude and between $125^{\circ} 22^{\prime}$ and $126^{\circ} 11.5^{\prime}$ East longitude (MSU 1995). The water surface area is about $3,087 \mathrm{~km}^{2}$ and the tide in the area is predominantly semidiurnal with two high and two low water level occurring in a day. Davao Gulf is a very large, deep ( $>1 \mathrm{~km})$, and semi-enclosed basin located south of Mindanao Island.

The gulf is comprised of four provinces, a new city, and one chartered city namely: Davao del Sur, Davao del Norte, Davao Oriental, Compostela Valley, the Island Garden City of Samal (IGACOS), and Davao City.

The axis of the bay is oriented from north to south with a broad mouth in the southern part. It has an irregular coastal geometry and its bathymetric contours show increasing depth towards the southern direction. Two major islands are located near the head of the gulf which partly blocks the entry of tidal currents and the propagation of long gravity waves.

The Philippine Atmospheric, Geophysical and Astronomical Services Administration (PAGASA) classified the western and northern part of Davao Gulf as type IV. On this side of the gulf, the climate has a more or less evenly distributed rainfall. The eastern portion has no pronounced dry season but it has a pronounced rainfall from November to January. The currents in Davao Gulf are dictated predominantly by the tide. The tidal ebbing and flooding govern the transport of mass land within and out of the gulf. The ebb currents would rush southward toward the mouth of the bay with a notable increase in current magnitudes at the narrow channel bordering Samal Island and the mainland. On the other hand, the flood currents would rush toward the head of the gulf with strong current deformation caused by Samal Island (Rivera 2002).

\section{Inventory of Boat and Gear}

The boat and gear inventory conducted by NSAP concentrates on the municipality where the sampling stations lie. The survey is once every year to determine the number of fishing boats and the kind of fishing gears used in fishing per sampling site. Gear inventory was based on its generic classifications and numeration using NSAP forms.

\section{Fishing Location in Davao Gulf}

The fishing activities on the fishing ground were monitored during NSAP sampling days. The fishing location was best estimated using the grid map (Navigational Map/Mercator projection) drawn to scale at 1:200,000. The grid map is composed of several cells where one cell is equal to one square nautical mile. Dead reckoning method was used to calculate the distance and determine the location of the sampled boat through fisher folks' interview.

\section{Sampling Procedures}

The sampling procedure was randomly done done in all sampling sites. The landing centers were stratified into commercial, major and minor municipal landing centers. The gathering and sampling of landed catch was done in two successive sampling days. Monitoring of commercial or major municipal landing centers fell on the first day, while day two was for minor municipal landing centers. There was an interval of one day every two days of sampling activities. Monitoring was simultaneous in all NSAP landing centers. The landed catch was observed every 20-21 days a month per sampling station or 10-11 days per landing center.

Interviews concentrated on fishing effort, fishing gears used, the name of the boat, fishing location, fishing gear working depth, and the number of fisher folks onboard. The catch was verified either partial or complete. The catch compositions of each specific gear were also determined whether fishing is with the use of multifishing gear. The catch and effort were determined per fishing gear per boat.

The length-weight data was recorded after the catch and effort information had been known and the 
sub-samples had been sorted down to species level. For species that grows $>30 \mathrm{~cm}$, the measurement was one (1) $\mathrm{cm}$ length interval while for species that grows $<30 \mathrm{~cm}$, the nearest mid length interval was $0.5 \mathrm{~cm}$. Large pelagic species that have stiff caudal fins (e.g. tuna) used the fork length measurement. However, the small pelagic species with soft caudal fins (e.g. Selar crumenophthalmus) used the total length measurement.

The raising factor (RF) was used in raising the catches of the total boats landed with the same fishing gear per sampling day. The same method was used in raising the length frequencies (LF) of individual species caught per fishing gear. The raising of subsample catch either in weights or in length frequencies was done since the monitoring was only conducted for 10 to 11 days per month per landing center. The monthly raising was also manipulated in direct proportion to the number of days in a month (BFAR/NSAP Manual Procedures).

Raising Factors (RF) are expressed in the following:

$$
\begin{aligned}
& R F_{1}=\frac{\text { Total weight sampled }}{\text { Subsample weight }} \\
& R F_{2}=\frac{\text { Total Boat Catch }}{\text { Total weight of samples }} \\
& R F_{3}=\frac{\text { Total no. of days in a month }}{\text { Sampling days }}
\end{aligned}
$$

\section{Procedure in the Analysis of Data}

The processing stage of length frequencies data underwent several manipulations. A percentileweighting scheme per fishing gear was introduced either in production or in yields and in length frequencies of subsample weights. The subsample weight of the length frequency distribution of a specific fishing gear was weighted against the subsample weights of the length frequencies of the other fishing gears in connection to how voluminous the sample weight was (i.e. sample weight of the length frequency distribution of surface gill nets against the sample weights of length frequency distributions of other fishing gears). The catch or yield was weighted against per fishing gear to zero in any anomaly; disturbances on how robust were the catch of hook and line against the catch of ring net or among any fishing gears monitored. The population parameters of the six commercially important small pelagic fishes in Davao Gulf were estimated and obtained using the FAOICLARM Fish Stock Assessment Tool (FiSAT).

The weighting scheme for landed catch and subsample weight of length frequencies per fish species is expressed in this manner:
Formula 1.

$$
W T \text { ave. }=\frac{\begin{array}{c}
\text { subsample weight of specific } \\
\text { fishing gear }
\end{array}}{\begin{array}{c}
\sum \text { weight of sub - ample of all } \\
\text { fishing gears }
\end{array}} \times 100
$$

Formula 2.

\section{$R F=$ total yield or catch $x$ result of formula}

The length frequencies data went through several routines using the FiSat I and II. The different routine in the analysis used the Powell-Wetherall plot, mortality estimation $(Z)$ of a steady-state sample, relative yield per recruit $(Y / R)$, and biomass per recruit $(B / R)$.

The Electronic Length Frequencies Analysis (ELEFAN) routine includes the routine of PowellWetherall plot and the scan of $\mathrm{K}$ values. The length growths using the Von Bertalanffy Growth Function (VBGF) is expressed in this equation:

$$
L_{\mathrm{t}}=\mathrm{L}_{\infty}\left(1-\mathrm{e}^{-\mathrm{K}(\mathrm{t}-\mathrm{t} 0)}\right)
$$

Where the length infinity $\left(\mathrm{L}_{\infty}\right)$ is the mean length of the old fish or the asymptotic length, growth curve $(\mathrm{K})$ is the rate of how fast the fish reached its length infinity, and $t$-zero (t0) is the age of fish at zero length.

In addition, the function of Powell-Wetherall plot using the length data from the subsample is expressed and based on the equation of Beverton and Holt (1956):

$$
\mathrm{Z}=\mathrm{K}\left(\mathrm{L}_{\infty}-\mathrm{L}\right) /\left(\hat{\mathrm{L}}^{-} \mathrm{L}\right)
$$

Where the total mortality coefficient is $\mathrm{Z}$, is the mean, and $\mathrm{L}$ is the smallest length of fish fully represented in the length-frequency data. The estimation of mortality rate coefficients computed from the catch curve used the formula below:

$$
\mathrm{Z}=\mathrm{F}+\mathrm{M} \text { and } \mathrm{E}=\mathrm{F} / \mathrm{Z}
$$

Where (F) is the fishing mortality, $(\mathrm{M})$ is the natural mortality, and (E) is the exploitation rate. Exploitation rate (E) was computed by dividing the fishing mortality (F) of the exploited stocks by the estimated total mortality $(Z)$ of each species.

The results obtained from the ELEFAN (Electronic length Frequency Analysis) routine were compared with the results from other routines like the Powell-Wetherall plot and the automatic search. The response surface analysis of growth was sometimes used to compare the results. Whatever method will confirm the best-fit of the $\mathrm{K}$ value on the given value of the length infinity $(\mathrm{L} \infty)$ was the one used in the analysis. 


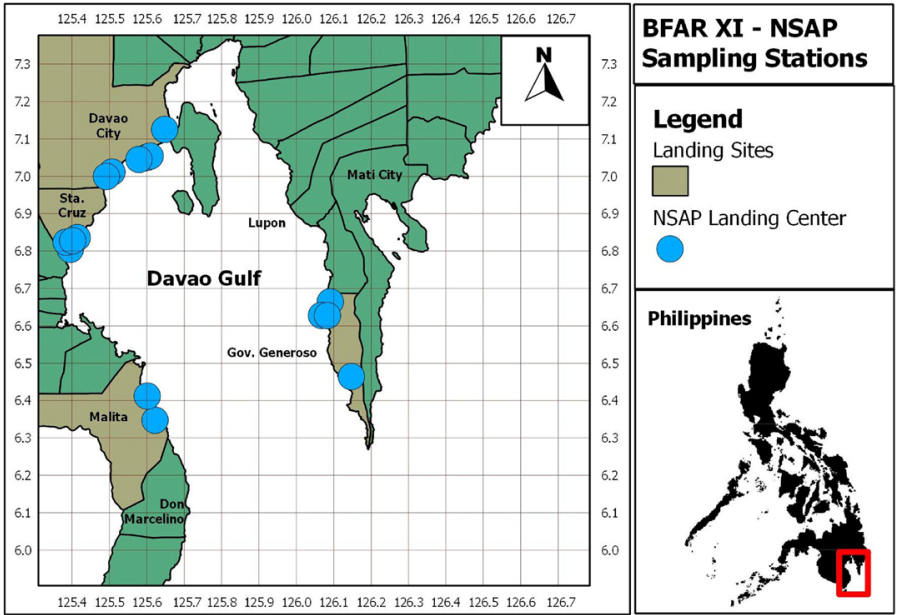

Figure 1. Map of Davao Gulf and BFAR XI-NSAP sampling stations and landing centers.

In addition, the sample bar graph routine in FiSAT under support menu was used to check the length frequencies data (time series data) in order to either proceed or not in the analysis since this routine will determine visually the progression of growth mode of a given data series per species.

The surplus production model (Potential Yield) was based from the total effort data using different parameters of the mean value (average) of the relative fishing effort by its gross tonnage, horsepower, and the catch per unit effort of specific fishing gears. The average number of fishing days spent by different fishing gears and the total numbers of boat landed per gear in a year were also used as the parameters in the analysis of the total effort.

Furthermore, the statistical mean of the total production per strata is used to multiply the total numbers of landing centers per strata was multiplied by the total numbers of landing centers per strata in the entire Davao Gulf. The raised production data per strata and the total effort data were plotted per year to estimate the potential yield of Davao Gulf.

The estimation of potential yield was analyzed using the following equations of Schaefer (1954) and Fox (1970) models:

Schaefer Model:

Fox Model:

$\frac{Y(t)}{f(t)}=a+b^{*} f(i) \quad \frac{Y(t)}{f(t)}=\exp ^{(\mathrm{c}+\mathrm{dxf(i))}}$

Where (Y) is the yield, (f) is the catch per unit effort, (b) is the slope, and (a) is the intercept.

Some data were analyzed using MICROSOFT EXCEL and ACCESS programs to maximize output results.

\section{RESULTS AND DISCUSSION}

\section{Sampling Stations}

The sampling stations of Davao Gulf were composed of Malita and Sta. Cruz of Davao del Sur; Davao City; and Lupon and Governor Generoso of Davao Oriental. The Davao City sampling station composed of Talomo, Bucana, Toril, and Matina Aplaya lies in the inner part of the gulf's head. Sta. Cruz sampling station was composed of Apo Beach, Bitaug, and Tuban. These landing centers were almost in the middle part of the gulf where Sta. Cruz is a nearby municipality of Davao City going to the southern part of Davao province. Malita sampling station which is found near the mouth of the gulf on the western side had two landing centers namely Sabang and Talucanga. On the other side, the Lupon sampling station was composed of three landing centers namely Aroma, Mandalihan and Cebolida. Governor Generoso sampling station had the following landing centers: Tibanban, Mabuhay, Jamboree A and B. These landing centers are located near the mouth of the gulf on the eastern side. There were five (5) sampling stations with 16 landing centers (Figure 1).

\section{Fishing Boat Inventory}

The gross tonnage of commercial fishing vessels is grouped into three categories according to RA 8550: the small scale commercial fishing vessels (3.1 GT-20 GT), medium scale commercial fishing vessels (20.1-150 GT) and the large scale commercial fishing vessels (150.1 GT and above). According to BFAR/MCS-11, the commercial ring netters in Davao Gulf range from 6.44 Gross Tonnage (GT) to 55.20 GT. These fishing vessels are made of wooden or steel hull and powered by an automotive diesel engine. 
Table 1. Fishing gears inventory and classification

\begin{tabular}{|c|c|c|c|c|}
\hline Sector & Gear Type & Fishing Gear & Local Name & $\begin{array}{l}\text { Number } \\
\text { of Units }\end{array}$ \\
\hline \multirow{3}{*}{$\begin{array}{l}\text { Commercial } \\
(2)\end{array}$} & & Ring Net & Likom/Kubkuban & 67 \\
\hline & & Bagnet & Basnig & 254 \\
\hline & & TOTAL & & 321 \\
\hline \multirow{26}{*}{$\begin{array}{l}\text { Municipal } \\
(25)\end{array}$} & Entangling Nets & Gill net w/ Scareline & Pamangsi/pamarungoy/pamalo & \\
\hline & & Surface/Drift Gill Nets & Patuloy/palutaw/pamante/sapaw & 3808 \\
\hline & & Encircling Gill Net & likos/pante & 316 \\
\hline & & Bottom Set Gill Net & Panteng palugdang & 984 \\
\hline & & Trammel net & Triple/double net & 299 \\
\hline & Impounding Nets & Cast Net & Laya/Traya & 67 \\
\hline & & Crab Liftnet & Bintol & 94 \\
\hline & & Beach seine & Baling & 373 \\
\hline & & Push net & Sudsud & 403 \\
\hline & Hook \& Lines & Multiple Hook and Line & Undak-undak/Pasol/Tuntun & 1682 \\
\hline & & Simple Hook and Line & Undak/Pasol & 5455 \\
\hline & & Bottom Set Long Line & Palangre & 1258 \\
\hline & & Tuna Handline & Pamariles/Pasol & 5967 \\
\hline & & Troll line & Subid-subid & 278 \\
\hline & & Squid Jig & Palaran/pangnukos & 5211 \\
\hline & & Multiple Hand line & Pasol & 8774 \\
\hline & & Tuna Long line & & 29 \\
\hline & Hand Instrument & Spear & Pana & 1142 \\
\hline & & Scoop net & Sikpaw/sapyaw & 1883 \\
\hline & & Gaff & & \\
\hline & & Squid luring device & Wiris & \\
\hline & Barrier and traps & Fish Corral & Bungsod & 203 \\
\hline & & Crab pot/lift net & Bintol/panggal & 1044 \\
\hline & & Fish pot/trap & Bubo & 745 \\
\hline & & Barrier Net & Pahubas & 37 \\
\hline & & TOTAL & & 40,052 \\
\hline
\end{tabular}

There were about 289 units of commercial fishing boats operating and 115 units were used directly for fishing (Armada 2002). There were about 1,168 registered commercial fish workers in the area.

On the other hand, there were 13,930 municipal fishing crafts and 13,725 of these were used in direct fishing. Only $43 \%$ of the municipal crafts were motorized and the rest (57\%) were sail or paddle driven. Of the total 18,393 municipal fisher folks, $75 \%$ were full-time fisher folks and 25\% were engaged in part-time basis (Armada 2002).

\section{Fishing Gears Inventory}

There were 27 types of fishing gears found in Davao Gulf. The two commercial types are the bag net and the ring net while the remaining 25 types are municipal fishing gears. Municipal fishing gears were classified into non-textile devices (e.g. hand instruments, barrier, and traps), and textile devices (e.g. lines to entangling/ impounding nets). The most common municipal fishing gears found in Davao Gulf were hook and lines (72\%), entangling nets (13\%), hand instruments $(8 \%)$, barriers and traps (5\%), and impounding nets (2\%) as can be seen in Figure 2.
The gill nets (surface or drift gill nets and bottom set gill nets) differed on the number of "banata" used. The length per "banata" of different kinds of gill nets are varied perhaps due to hanging ratio applied. They also differed in mesh size and working depth.

The line fishing also varied on the number and size of hooks that were used and the length and size of the mainline.

The municipal fishermen in Davao Gulf used two or more fishing gears (e.g. hook and line, gill nets, handline, etc.). Whenever catch for one fishing gear is nil, fishermen would shift to hook and line or vice versa for a possible catch. However, there were fishing gears that operate completely year-round like gill nets, hook and line, multiple hand line, and others. (Table 1).

\section{Fishing Location in Davao Gulf}

Partial data on fishing location for three years, CY's 2000-2002, were grouped by grid cell and mapped to show the overall extent of fishing activities within Davao Gulf (Fig. 3). Dense aggregation of fishing activity was observed on the western side near the gulf's opening and inward, south and in between IGACOS and Davao City. The eastern side and west most portion of the gulf were 
(a)

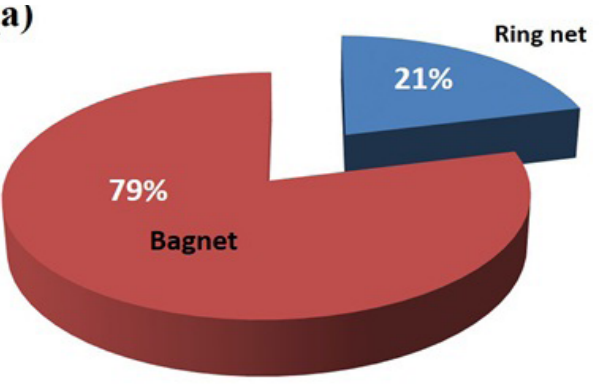

Commercial Fishing Gears

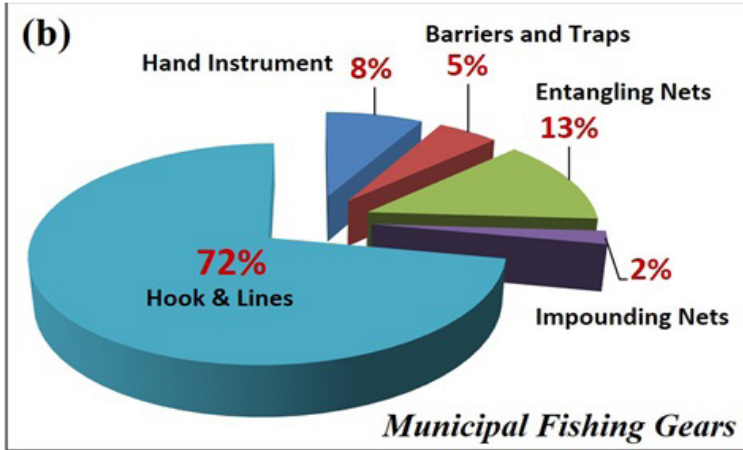

Figure 2. Distribution of (a) commercial and (b) municipal fishing gears operating in Davao Gulf.

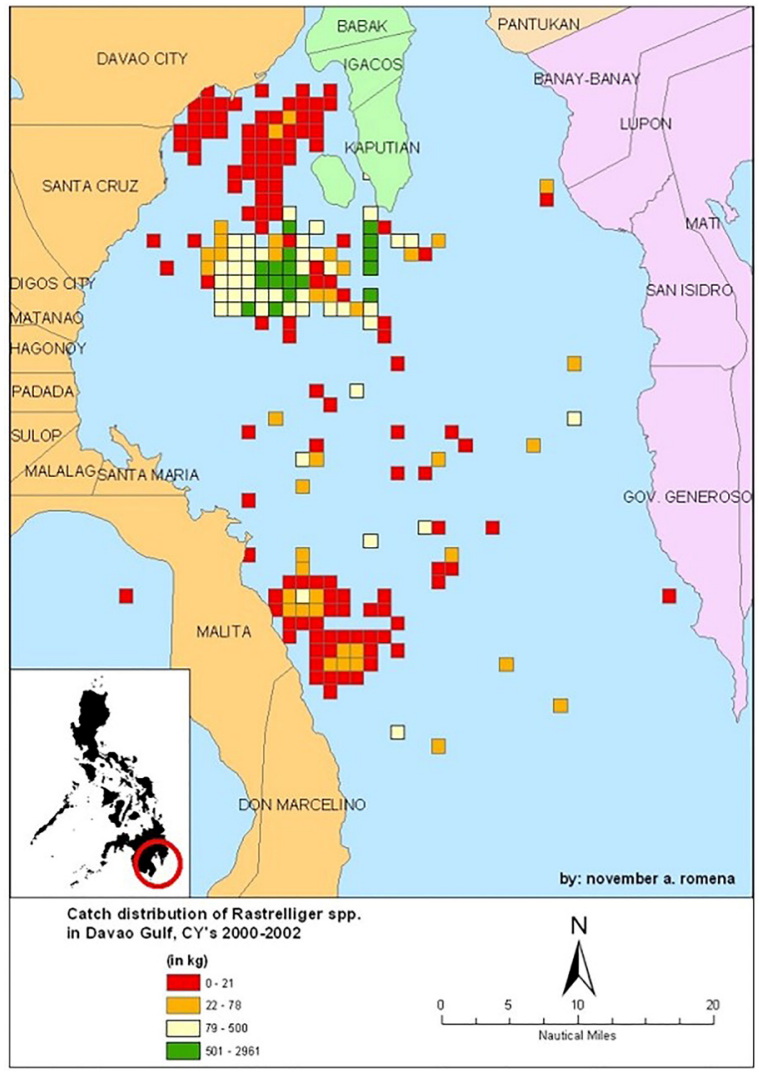

Figure 3(a). Catch distribution of Rastrelliger spp. (CY 2000-2002).

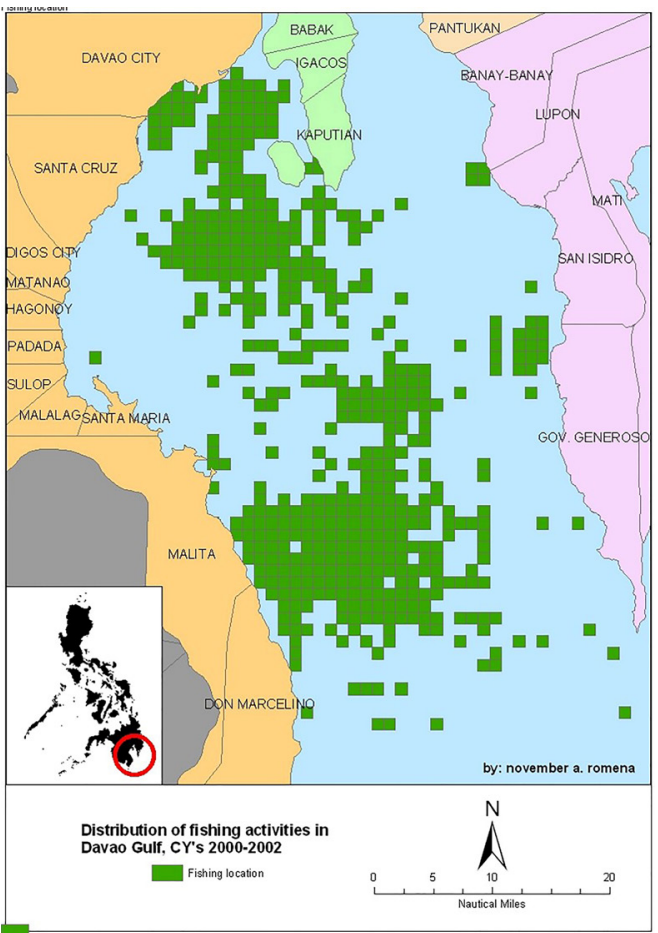

Figure 3. Extent of fishing activities in Davao Gulf (CY 2000-2002).

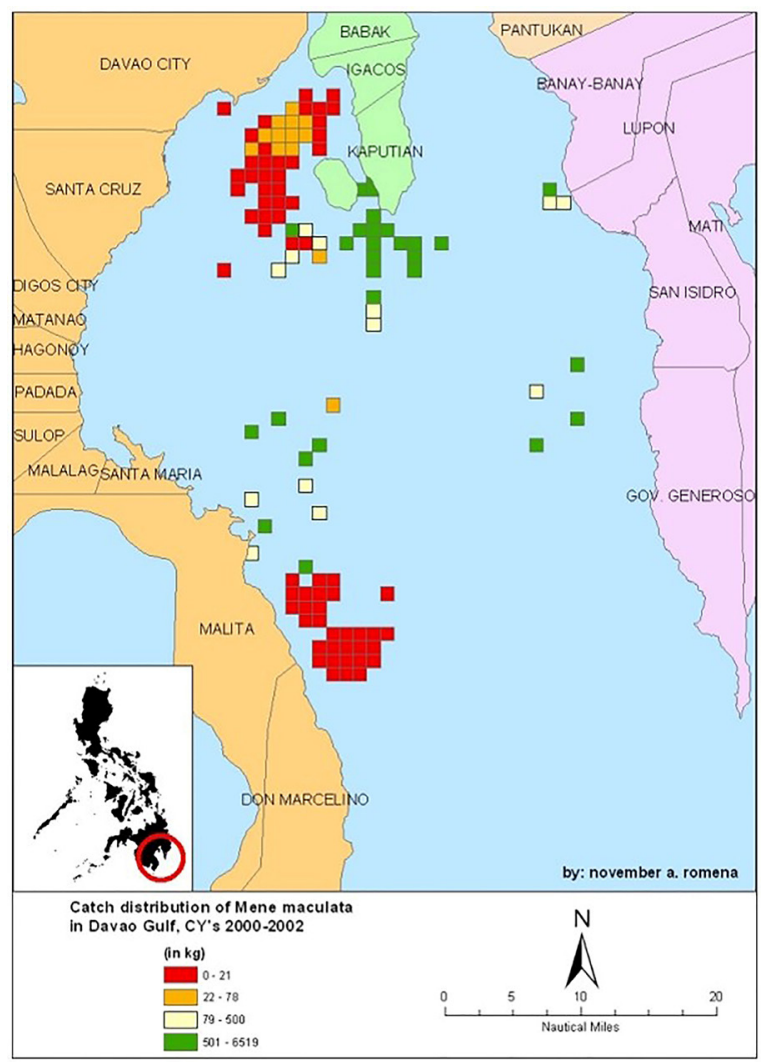

Figure 3(c). Catch distribution of Mene maculata in Davao Gulf (CY 2000-2002). 


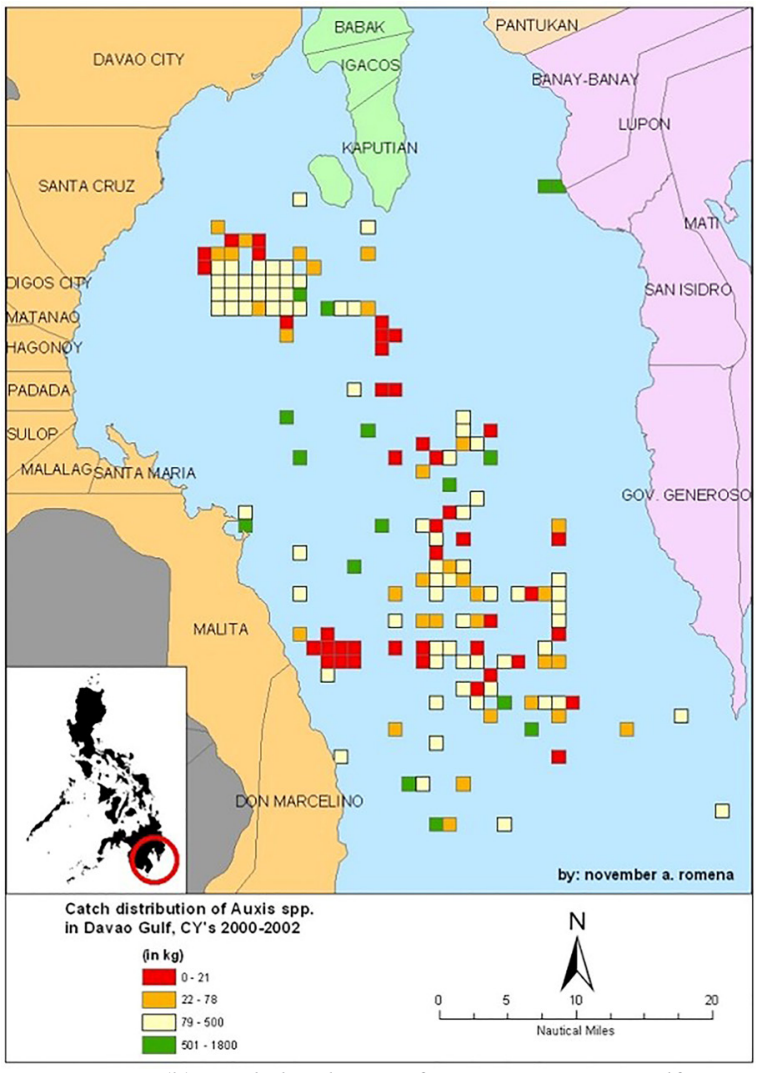

Figure 3(b). Catch distribution of Auxis spp.in Davao Gulf (CY 2000-2002)

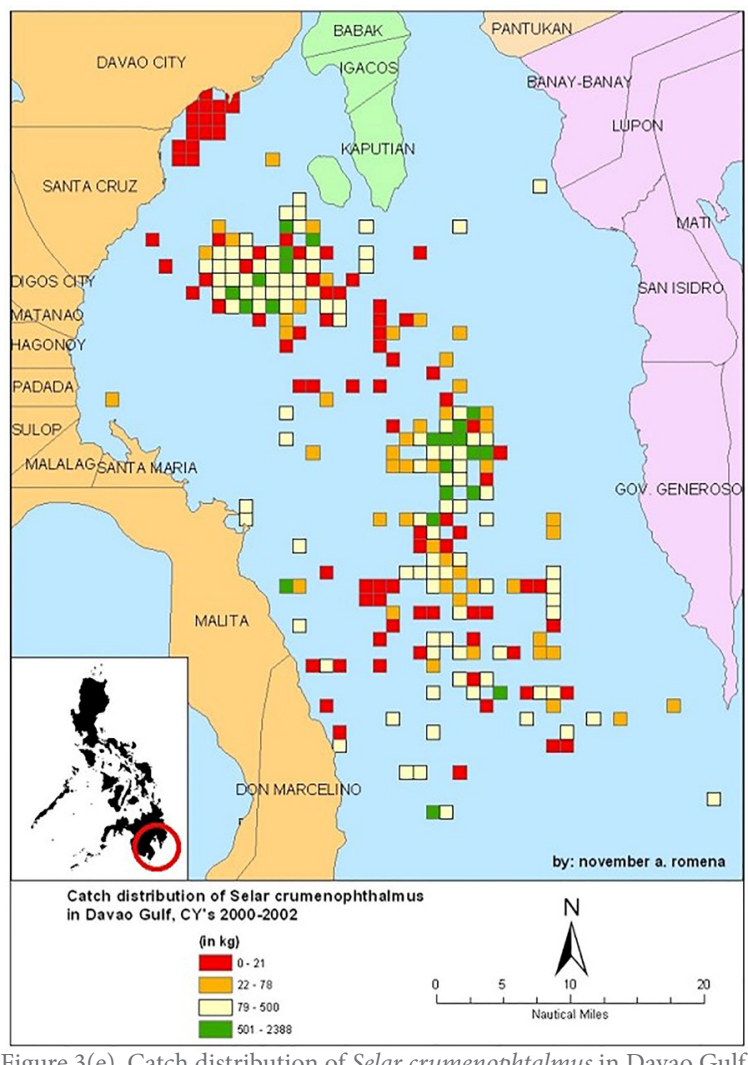

Figure 3(e). Catch distribution of Selar crumenophtalmus in Davao Gulf (CY 2000-2002).

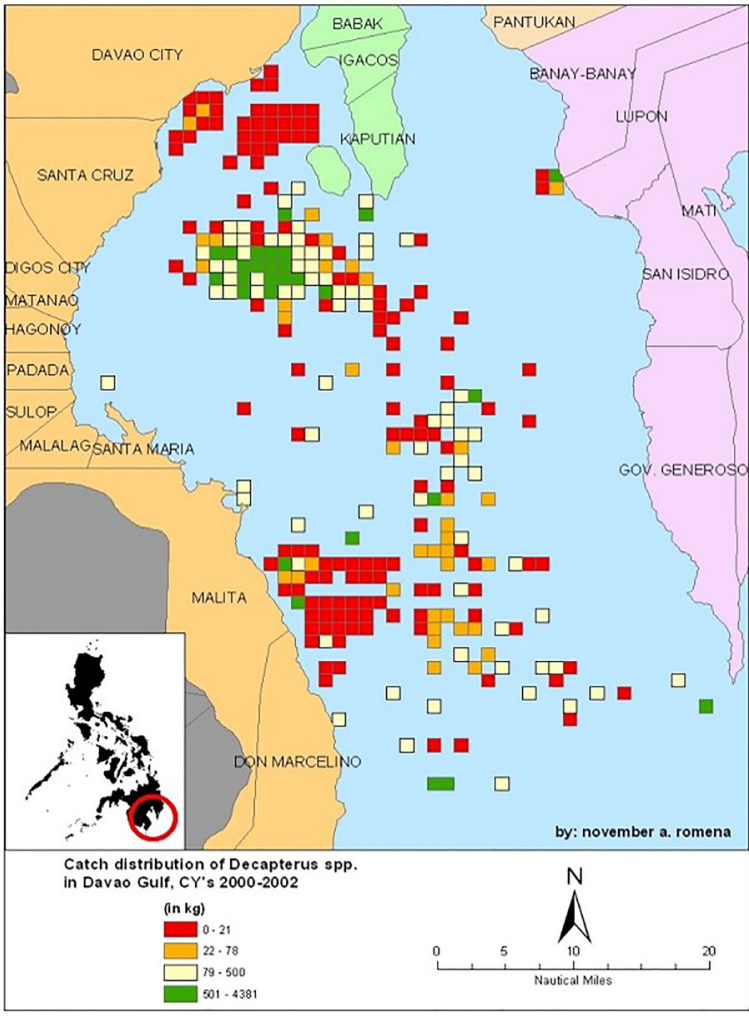

Figure 3(d). Catch distribution of Decapterus spp. in Davao Gulf (CY 2000-2002).

relatively unfilled due to lack of data. Higher counts of fishing operation were present near the coast of Davao City, in between mainland Davao and IGACOS (Island Garden City of Samal), offshore fronting Sta. Cruz, Malita, and fronting Gov. Generoso and scattered in the mid portion of the gulf (Romena and Villanueva 2002, unpublished).

The top six species caught in Davao Gulf were selected through the ranking of total landed catch or weights in time series data. The catch distribution per species was mapped in color variation based on previous quartile values (Figures 3 to $3 \mathrm{e}$ ). Though the catch distribution of all the species was dispersed within the mid portion of the gulf, observable aggregation of the optimal catch was evident in the offshore fronting Sta. Cruz for the species Auxis spp., Decapterus spp., Rastrelliger spp., and Selar crumenopthalmus. Catch distribution of Mene maculata showed high catch level on the southern part of Samal Island, Davao del Norte (Romena and Villanueva 2002, unpublished).

\section{Landed Boat per Year}

The landed boats refer to the number of times the boat went out for fishing in a year. The boat count is the impartiality on the number of units or the magnitude of boats landed in a year per landing center in relation to the variation of landed catch and or fishing seasonality of the same period caused by typhoons or monsoons. 


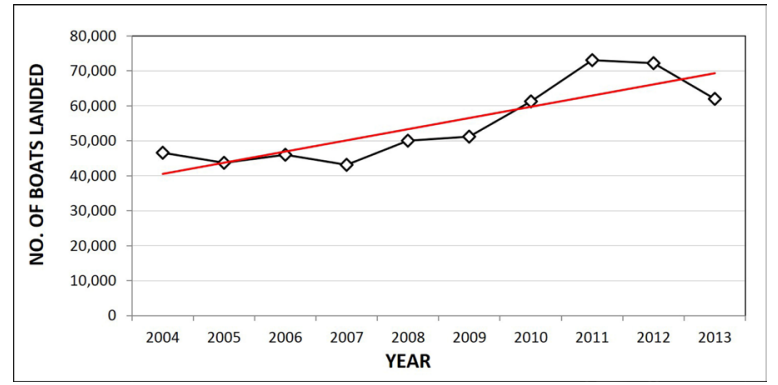

Figure 4. Annual boat landings for CY 2004-2013 (raised data).

The data shows that the number of boats landed for 2004 increased from 46,594 boats to 62,007 boats in 2013 (Figure 4).

\section{Landed Boat per Strata}

The monitoring of landed catch was simultaneous in all NSAP landing centers in a stratified manner. There were 5 out of $8(63 \%)$ commercial landing centers; 3 out of 83 (4\%) major municipal landing centers, and $7 \%$ or 4 out of 54 landing centers for minor municipal that were monitored in the entire Davao Gulf.

The overall trend of the landed boats in commercial landing centers showed a slight increase from 2004 to 2013. In 2004, there were 6,573 boats and increased slightly to 6,950 in 2012 ; however, there was a sudden drop in 2013 to 5,857 boats (Figure 5).

The major municipal landing centers showed a considerable increase in the number of boats landed from 19,616 units in 2004 to 41,256 boats in 2013 (Figure 6).

On the other hand, minor municipal landing centers showed a constant trend (Figure 7). The data

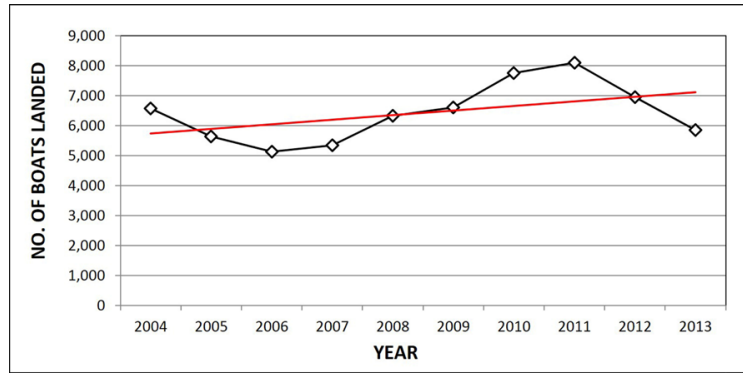

Figure 5. Landed boats in commercial landing centers for CY 2004-2013 (raised data).

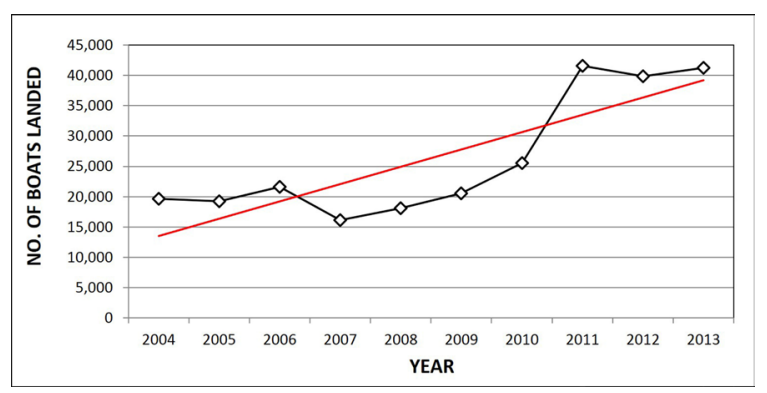

Figure 6. Landed boats in major municipal landing centers for CY 2004-2013 (raised data)

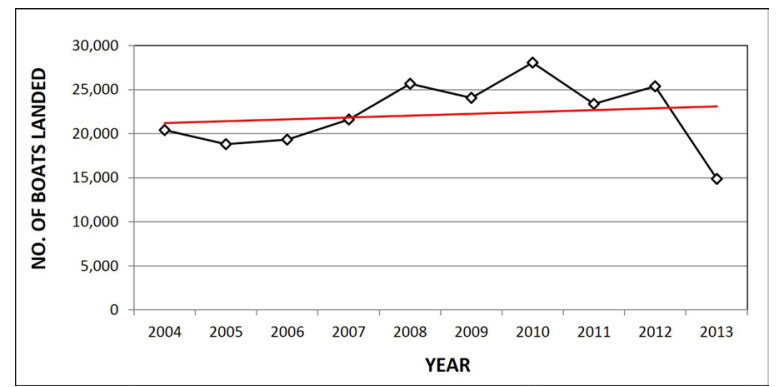

Figure 7. Landed boats in minor municipal landing centers for CY 2004-2013 (raised data).

analysis showed that the total boats landed in 2013 abruptly dropped to 14,894 units compared to 20,405 landed boats recorded in 2004.

\section{Yield per Strata}

The annual average yield per landing categories showed that minor municipal landing centers have a remarkable decrease from CY 2004 to 2013, from 19.43 MT to 14.94 MT (Figure 8). Contrary to major municipal landing centers, it showed an increasing trend for the same period from 14.81 MT in 2004 to 57.67 MT in 2013 (Figure 9).

The commercial landing centers also showed a significant increase on the landed catch from 161.28 MT in 2004 to $216.46 \mathrm{MT}$ in 2013 (Figure 10).

The commercial, major, and minor municipal landing centers contributed to about 2,750 MT (84\%), 337.65 MT (10\%), and 180.7 MT (6\%), respectively, on the annual average landed catch from 2004 to 2013 . The average yield for the entire Davao Gulf was about 326.9 MT per annum for all strata.

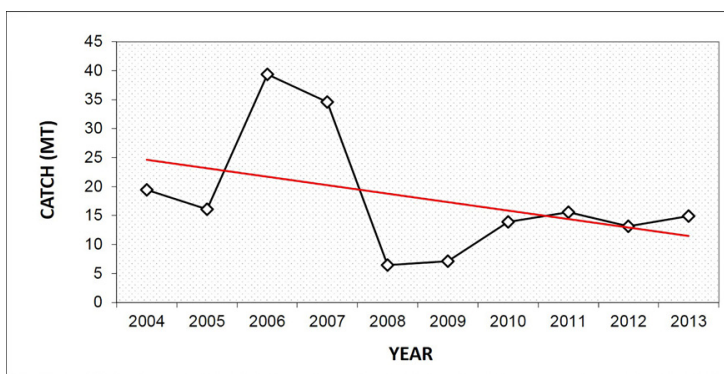

Figure 8. Annual average yield in minor municipal landing centers (CY 2004-2013).

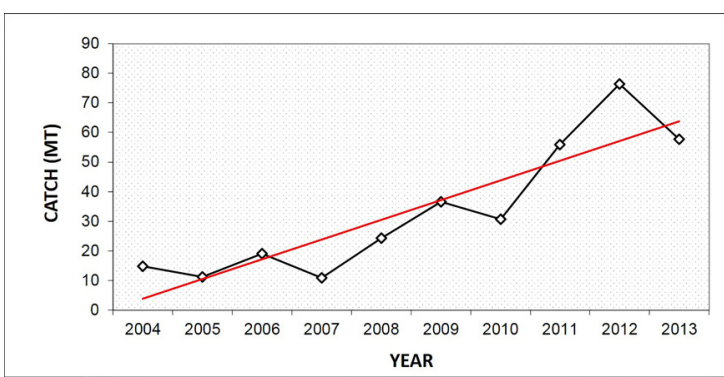

Figure 9. Annual average yield in major municipal landing centers (CY 2004-2013) 


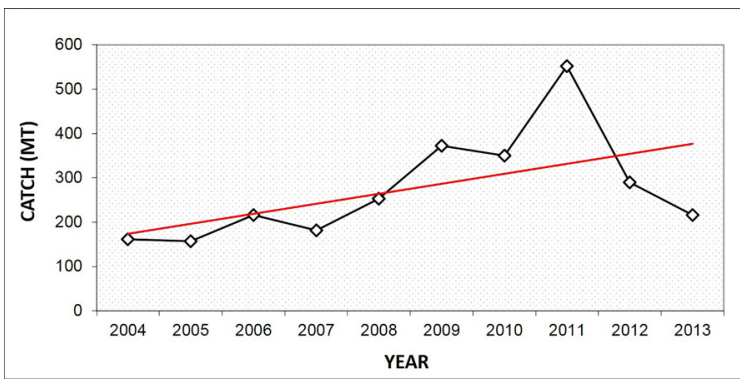

Figure 10. Annual average yield in commercial landing centers (CY 2004-2013).

\section{Estimated Catch of Commercial and Municipal Gears}

Figure 11a shows that the estimated total catch of commercial fishing gears against municipal fishing gears is significant. The year 2011 recorded the highest in terms of production in metric tons in ten years' time. The figure illustrates that commercial fishing gears contributed about $88 \%$ or $3,424.11$ MT to the total landed catch compared to municipal fishing gears which is only $12 \%$ or 487.77 MT. Hence, commercial gears contributed the largest in terms of production in Davao Gulf for CY 2004-2013 (Figure 11b).

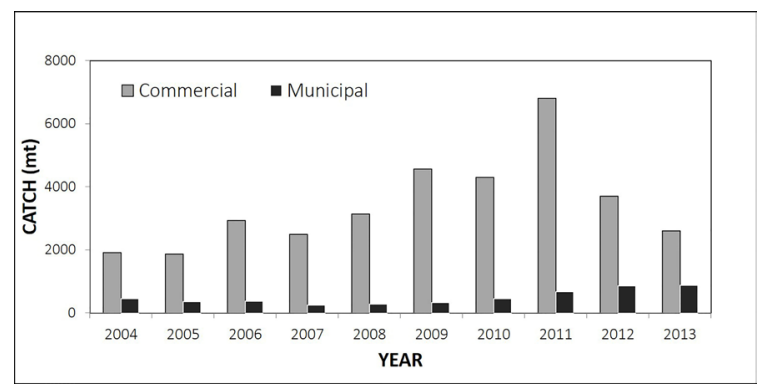

Figure 11(a). Estimated catch of commercial and municipal gears (CY 2004-2013).

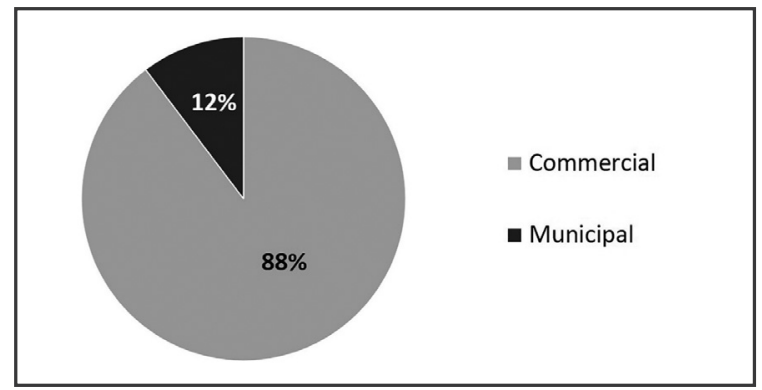

Figure 11(b). Average catch percentage of commercial and municipal fishing gears (CY 2004-2013).

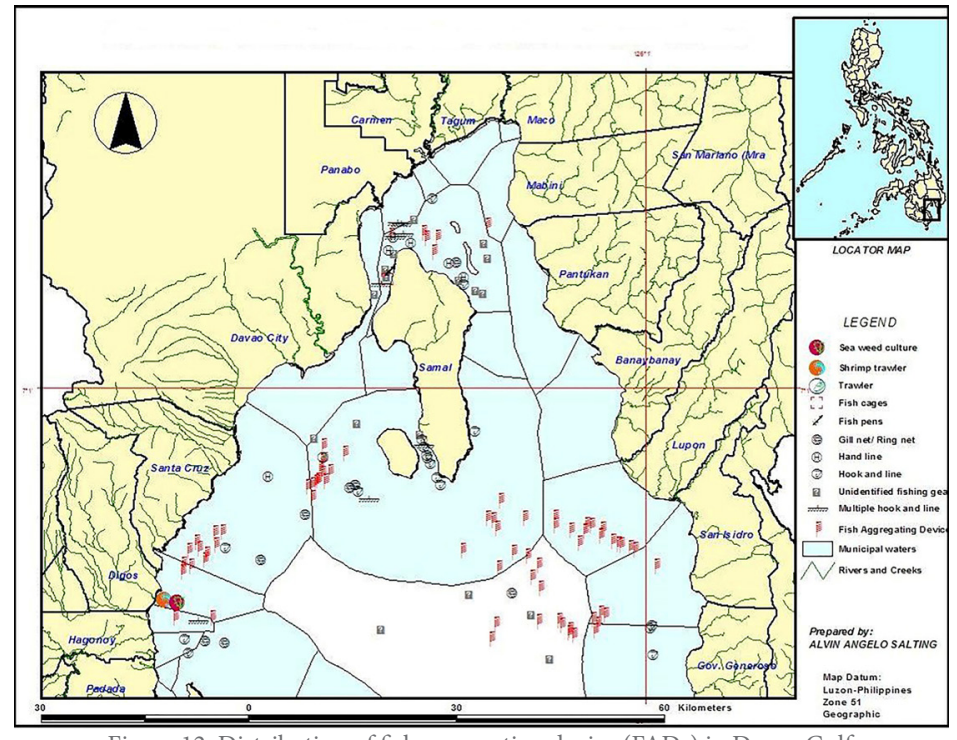

Figure 12. Distribution of fish aggregating device (FADs) in Davao Gulf.

\section{Commercial Fishing Gears}

The fish-aggregating device (FAD) locally known as "payao" are scattered around Davao Gulf. Most of the payaos are found within the municipal waters where the commercial ring nets and bag nets are fishing (Figure 12).

Ring nets are very dependent on "payao" except if there is a presence of large free school en route to target payaos. A day before the ring net is set, the dive master (Busero) conducts the underwater survey from several owned payaos and estimate the school of fish and decides which payao is to be prioritized for the setting. If the two payaos are close enough, one payao is towed and the payout of the net takes place in one setting.

\section{Ring net (payao)}

The Selar crumenophthalmus comprised 32\% of the catch and dominated the total catch of ring net in payao from CY 2004 to 2013. The average production per year was 89.7 metric tons, followed by Decapterus macarellus at $45.5 \mathrm{MT}$ (16\%). Other species caught were: 
Decapterus macrosoma with an average of $31.5 \mathrm{MT} /$ year (11\%), Katsuwonus pelamis at $23.3 \mathrm{MT} /$ year (8\%), and Auxis rochei (6\%) at $16.4 \mathrm{MT} /$ year.

On the contrary, the least dominant species was the Rastrelliger brachysoma at $5.7 \mathrm{MT} /$ year (2\%) while other species caught had an average production per year of $30.7 \mathrm{MT} /$ year (11\%) (Figure 13).

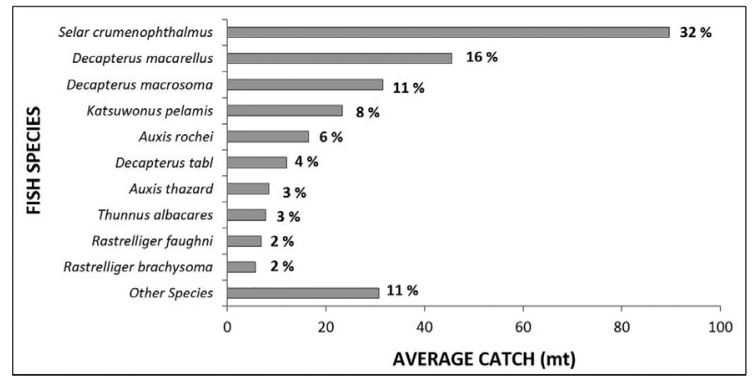

Figure 13. Average landed catch of ring net in payao (CY 2004-2013).

\section{Ring net (free school)}

For CY 2004-2013 dominant catch compositions of ring net in free school were Mene maculata (41\%) with an average yield of 17.2 MT/year and Katsuwonus pelamis (19\%) at $7.9 \mathrm{MT} /$ year. Species like Thunnus albacares, Sardinella gibbosa, Auxis rochei, and Rastrelliger brachysoma comprised the $2 \%$ of the catch with an average of 0.6-0.8 MT/year. On the other hand, the species Decapterus macrosoma, Decapterus tabl, Elagatis bipinnulata, and Auxis thazard comprised only $1 \%$ of the average landed catch of ring net in free school which is about $0.4 \mathrm{MT} /$ year (Figure 14).

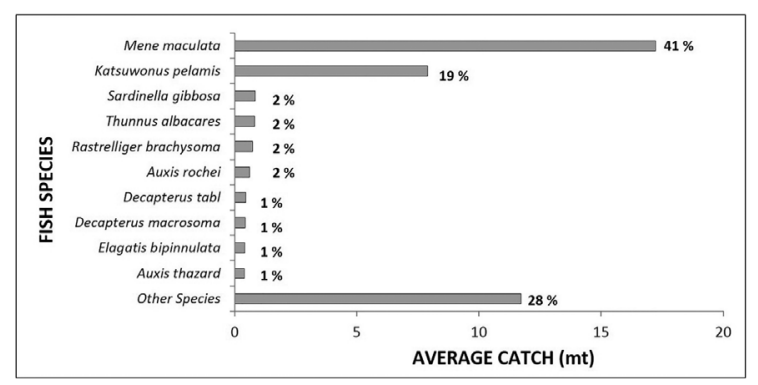

Figure 14. Average landed catch of ring net in free school (CY 2004-2013).

Bag net

The ten percent (10\%) catch compositions of bag net came from Auxis rochei which is about $3.31 \mathrm{MT} /$ year followed by Stolephorus spp. and Decapterus macrosoma at $6 \%$ each with an equivalent of $2.2 \mathrm{MT} /$ year. The Selar crumenophthalmus and Rastrelliger faughni both comprised $4 \%$ or about $1.7 \mathrm{MT} /$ year of the average landed catch (Figure 15).

The bag net was intended to catch anchovies (Stolephorus spp.), a fish species that is already mature in its small size. However, the catch composition showed that Stolephorus spp. only constituted $6 \%$ or about 2.0

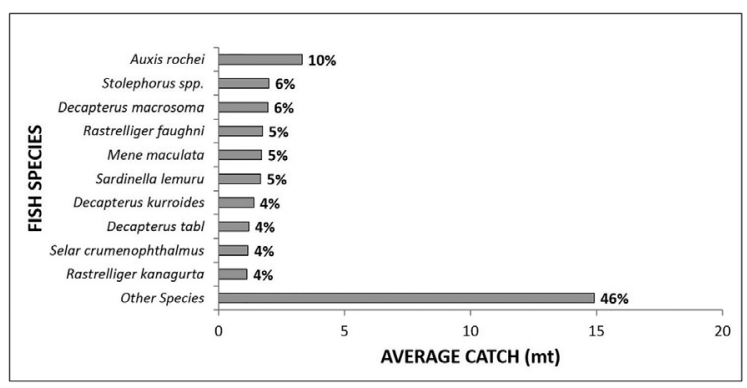

Figure 15. Average landed catch of bag net (CY 2004-2013).

MT/year of the landed catch of bag net compared to other species that grows more than or equal to $30 \mathrm{~cm}$ such as Auxis rochei.

The target species like anchovies was not the dominant catch. This gear can exploit a variety of fish species regardless of size due to its fine mesh net. Bag nets were also operated more in near shore municipal waters. The results could possibly show that these gears have been too effective in targeting species other than anchovies.

\section{Catch Per Unit Effort of Commercial Gears}

\section{Ring net (payao)}

The average production (raised data) for ring net payao in Davao Gulf for CY 2004-2013 was at 3,069.62 $\mathrm{MT} /$ year and the average number of boats landed per year was 5,291 units. The CPUE of ring net in payao showed a decreasing trend which is correlated with the declining average CPUE from $5,901.71 \mathrm{~kg} /$ day in 2004 to $1,606.72$ $\mathrm{kg} /$ day in 2013 (Figure 16).

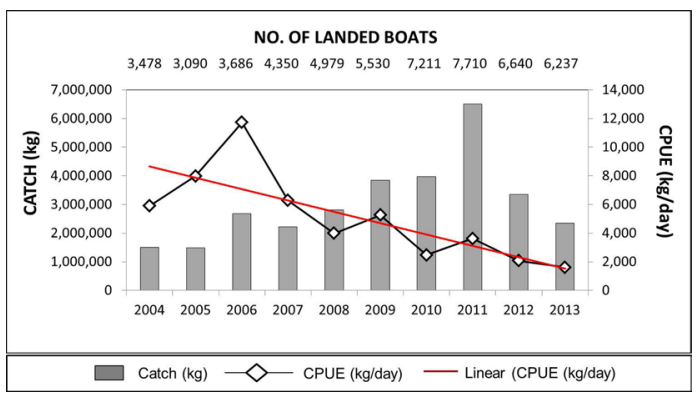

Figure 16. Catch per unit effort (CPUE) of ring net in payao (CY 2004-2013).

\section{Ring net (free school)}

The average production of ring net in free school for CY 2004-2013 was at 199.25 MT/year, the average CPUE per year was about $6,174.52 \mathrm{~kg} / \mathrm{day}$, and the average number of boats landed was 451 units/year. However, the CPUE trend for ten years period was also in a decreasing trend (Figure 17).

\section{Bag net}

The average production of commercial bag net was $122.21 \mathrm{MT} /$ year and the average landed boats for 


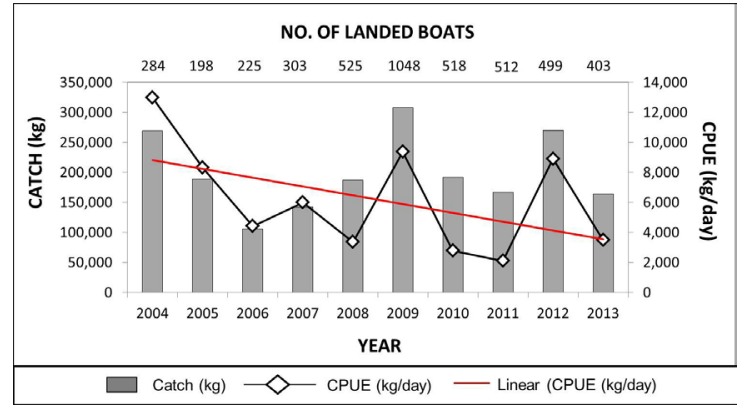

Figure 17. Catch per unit effort (CPUE) of ring net in free school (CY 2004-2013)

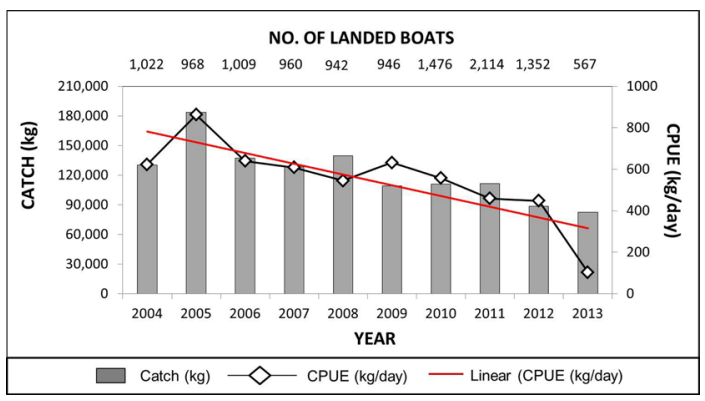

Figure 18. Catch per unit effort (CPUE) of bag net

(CY 2004-2013).

bag net was 1,136 units per year. The catch per unit effort from $668.37 \mathrm{~kg} /$ day in 2004 decreased to $103.16 \mathrm{~kg} /$ day in 2013. The total landed catch and the total landed boats with bag net were distinctly decreasing as well as the CPUE trend (Figure 18).

\section{Annual Catch per Species}

The production of Auxis rochei for CY 20042014 showed a decreasing trend from $127,282.29 \mathrm{~kg}$ in 2004 to $70,662.31 \mathrm{~kg}$ in 2013 (Figure 19).

The catch of Mene maculata also decreased from $387,716.97 \mathrm{~kg}$ to $67,065.37 \mathrm{~kg}$ (Figure 20). The Rastrelliger faughni has an increasing trend from CY 2004-2013. From $64,351.72 \mathrm{~kg}$ in 2004 , it increased to $159,433.45 \mathrm{~kg}$ in 2013 (Figure 22).

An increased production was also observed in species Decapterus tabl (Figure 22), Decapterus macarellus (Figure 23), and Selar crumenophthalmus (Figure 24). In 2004 , the production estimate was recorded at 203,014.85 $\mathrm{kg}, 130,000.1 \mathrm{~kg}$, and $351,711.46 \mathrm{~kg}$ for these species respectively and the annual harvest of these species increased gradually in ten years.

\section{Relative Abundance}

The relative abundance of fish species recorded in 2004 was 60 families and 436 fish species. There were 52 species under the family Carangidae, 35 species of Serranidae, 29 species under Lutjanidae, 20 species of the family Lethrinidae, and 19 species under Scombridae.

In the year 2009, an abrupt decline of the number of species caught was evident. There were 52 families

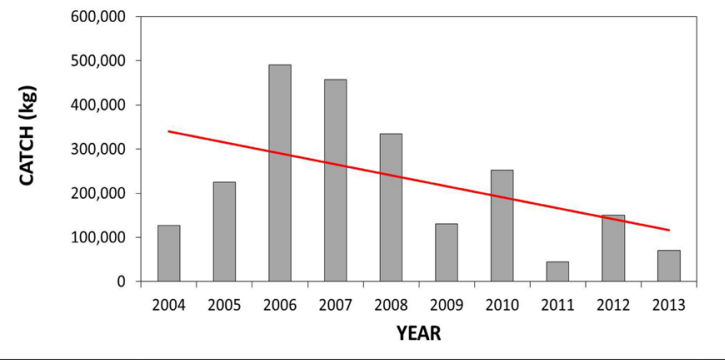

Figure 19. Annual harvest of Auxis rochei (CY 2004-2013).

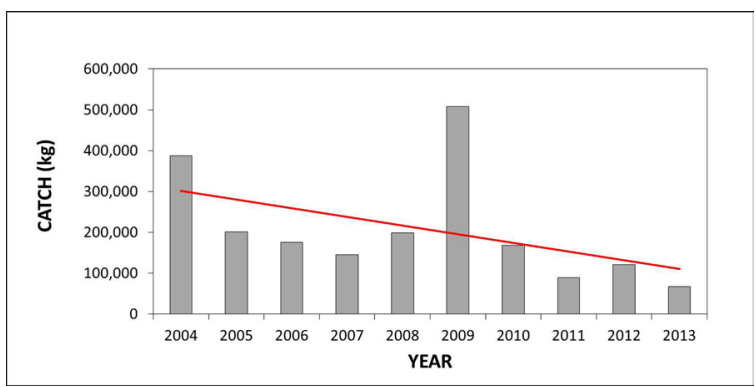

Figure 20. Annual harvest of Mene maculata (CY 2004-2013).

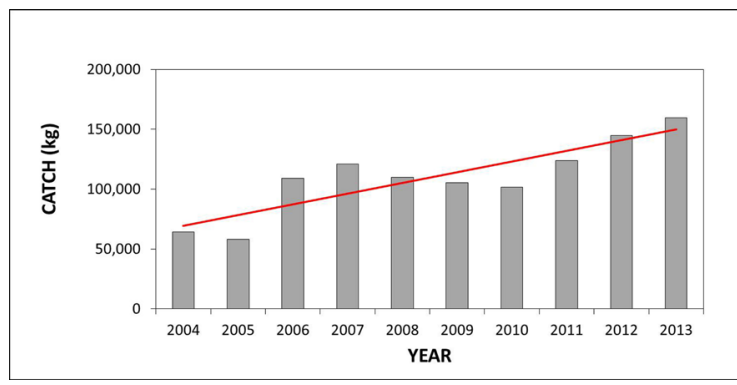

Figure 21. Annual harvest of Ratrelliger faughni (CY 2004-2013).

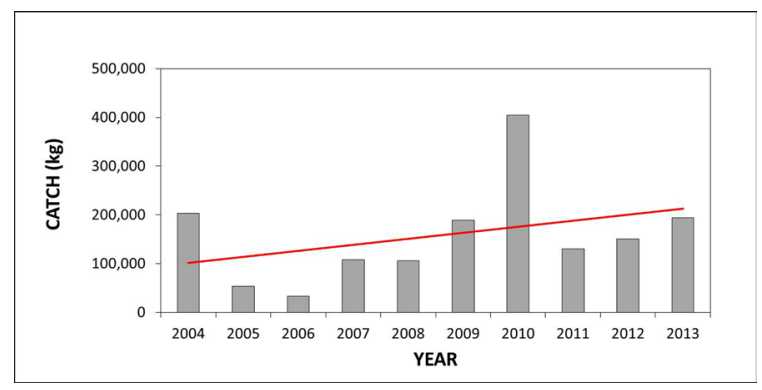

Figure 22. Annual harvest of Decapterus tabl (CY 2004-2013).

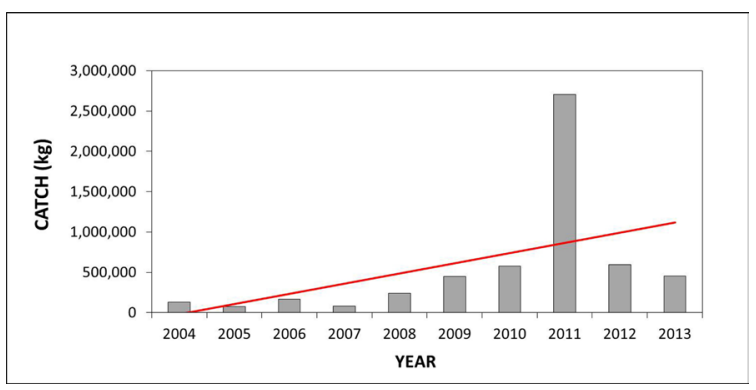

Figure 23. Annual harvest of Decapterus macarellus (CY 2004-2013). 
and 254 species. The family Carangidae decreased significantly to 34 species, the Lutjanidae and Serranidae families dropped to 20 species, the Scombridae and Lethrinidae declined to 17 and 12 species respectively. The year 2009 showed a decline in the number of fish species caught.

On the other hand, for CY 2013 the species composition increased to 316 species in 58 families which is an increase of $24.41 \%$ in the number of species since 2009. On the contrary, the number of species and families declined in a span of ten years' time, from CY 2004 which is from 60 to 58 families and from 436 to only 316 fish species in the year 2013. The family Carangidae has 33 species, 21 species of Serranidae, and 18 species of Scombridae.

The linear trend of the total number of species from the calendar year 2004 to 2013 showed a decline in the number of species (Figure 25).

The family Carangidae being the most dominant family of species caught in Davao Gulf recorded a total number of 52 species in 2004 and decreased to 33 species in 2013. The same with families Scombridae and Serranidae having 19 and 35 species in CY 2004 decreased to 18 and 21 species respectively for CY 2013.

The top families recorded for a span of ten years were the families of Carangidae, Scombridae, Serranidae, and Lutjanidae.

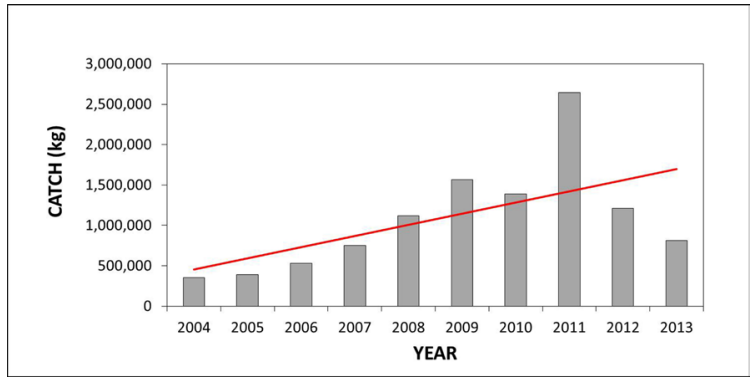

Figure 24. Annual harvest of Selar crumenophthalmus (CY 2004-2013).

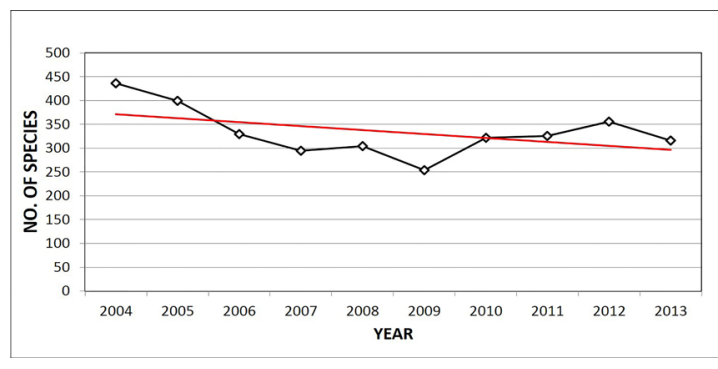

Figure 25. Linear trend of species caught in Davao Gulf (CY 2004-2013).

\section{Length Frequency Distribution and Length at Maturity} (Lm)

The length frequency data of the commercially important small pelagic fishes in Davao Gulf was recorded in CY 2013 to determine the catch percentage of juveniles caught by commercial fishing gears ring net and bag net.
Table 2 . The average length at $50 \%$ captivity $\left(\mathrm{L}_{50}\right)$ for ${ }^{\star} \mathrm{CY} 2004$ 2013 and the length at maturity of the commercially important small pelagic fishes in Davao Gulf.

\begin{tabular}{lcc}
\hline Small pelagic fish species & Ave. $\mathrm{L}_{50}{ }^{*}(\mathrm{~cm})$ & $\mathrm{Lm}(\mathrm{cm})$ \\
\hline Auxis rochei & 19.20 & 22.00 \\
Mene maculata & 13.52 & 14.00 \\
Rastrelliger faughni & 12.36 & 15.50 \\
Decapterus tabl & 14.50 & 16.00 \\
Decapterus macarellus & 21.06 & 22.00 \\
Selar crumenophthalmus & 18.92 & 16.50 \\
\hline
\end{tabular}

The length at maturity $(\mathrm{Lm})$ is the average length of fish of a given population that is sexually mature for the first time. The Lm of all the species included in the study was computed using the raw data calculated in FishBase. Lm of each species are listed in the third column of Table 2.

The length data of Auxis rochei ranged from 7.5 to $36 \mathrm{~cm}$. Smaller sizes of fish were the usual catch of bag net in terms of length class while the ring net are catching sizes that ranged from 10 to $36 \mathrm{~cm}$. Ring net caught 212,690 individuals (84\%) of $A$. rochei which are juveniles while the bagnet caught 77,960 individuals (100\%) of which are also juveniles (Figure 26).

The length class distribution of Mene maculata caught by ring net and bagnet ranged from $9.5 \mathrm{~cm}$ to 15 $\mathrm{cm}$. The ring net and bag net catches were composed of 247,570 individuals (96\%) and 9,710 individuals (87\%) respectively which are all juveniles (Figure 27).

Furthermore, the lengths of Rastrelliger faughni ranged from $8 \mathrm{~cm}$ to $23 \mathrm{~cm}, 52 \%$ of which were harvested by ring net. The catch of bag net was also composed of sizes less than $15 \mathrm{~cm}$ and are $99 \%$ juveniles (Figure 28 ).

The length class distribution of Decapterus tabl ranged from 8 to $22.5 \mathrm{~cm}$, both ring net and bag net catch were $80-99.9 \%$ juveniles. Only a remaining of $0.1-20 \% D$. tabl were caught matured for both gears (Figure 29).

The length data of Decapterus macarellus caught by ring net ranged from 10 to $34 \mathrm{~cm}$ while catch of bag net was not recorded. Figure 30 shows that $64 \%$ of this species was caught in sizes lesser than the length at maturity of 22 $\mathrm{cm}$ while the remaining $36 \%$ are already matured.

Consequently, the lengths recorded for Selar crumenophthalmus ranged from 7.5 to $25.5 \mathrm{~cm}$. With this, only $38 \%$ of the catch was immature given the wide distribution of sizes caught by ring net. However, catch of bag net was composed of $100 \%$ juveniles as shown in Figure 31 .

\section{Growth and Mortality Estimates}

\section{Length at $50 \%$ captivity $\left(\mathrm{L}_{50}\right)$}

Using the probabilities of capture routine of FiSAT, the results plotted per year shows that the $\mathrm{L}_{50}$ of small pelagic species caught by commercial ring net and bag net has declined which means smaller sizes of fish are 


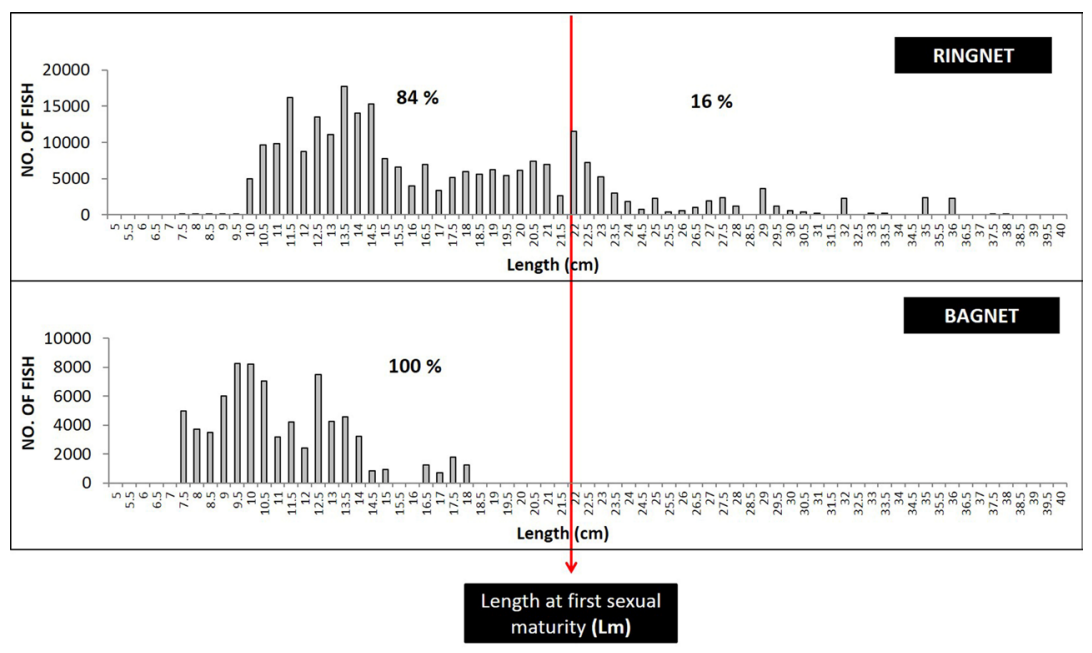

Figure 26. Length frequency distribution of Auxis rochei (CY 2013, $\mathrm{Lm}=22 \mathrm{~cm}$ ).

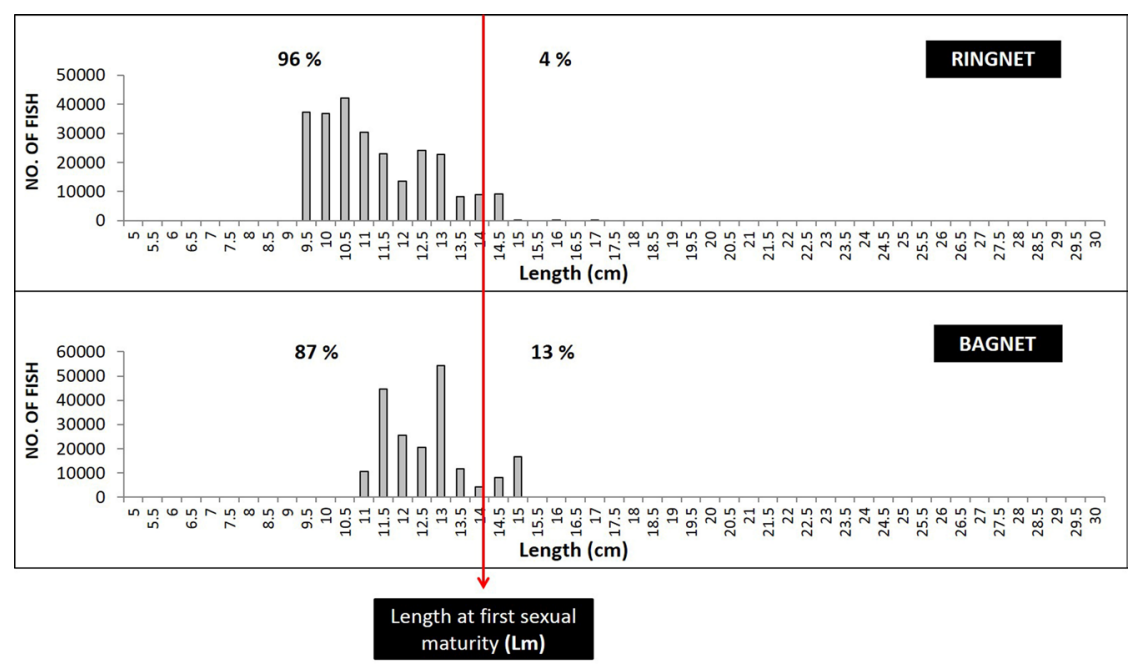

Figure 27. Length frequency distribution of Mene maculata (CY 2013, $\mathrm{Lm}=14 \mathrm{~cm}$ ).

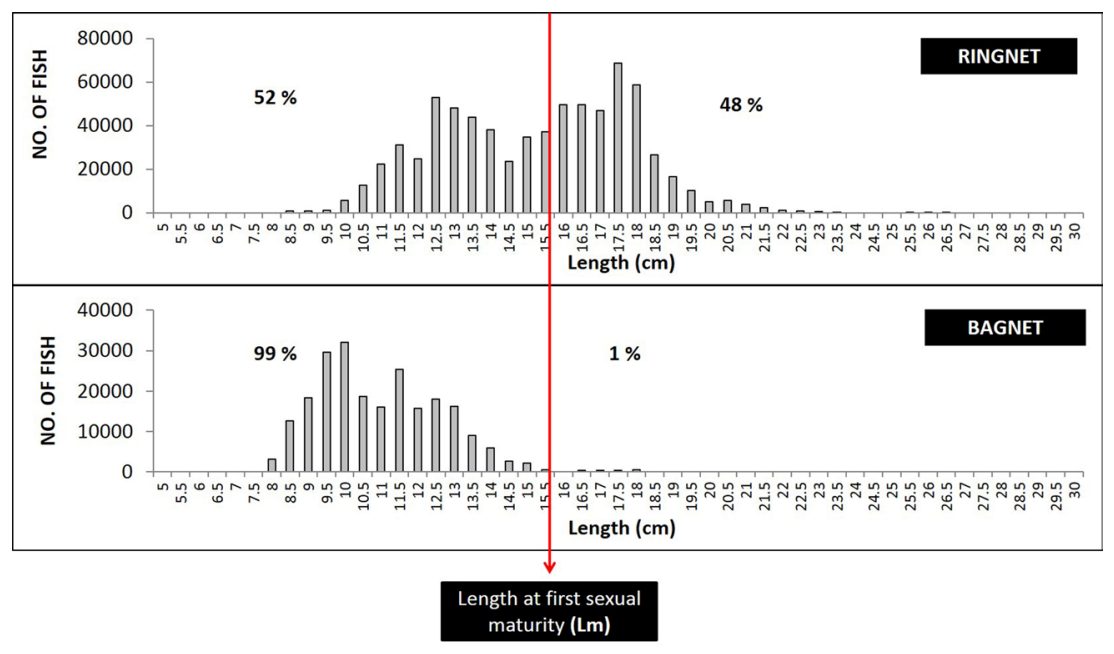

Figure 28. Length frequency distribution of Rastrelliger faughni

(CY 2013, $\mathrm{Lm}=15.5 \mathrm{~cm}$ ). 


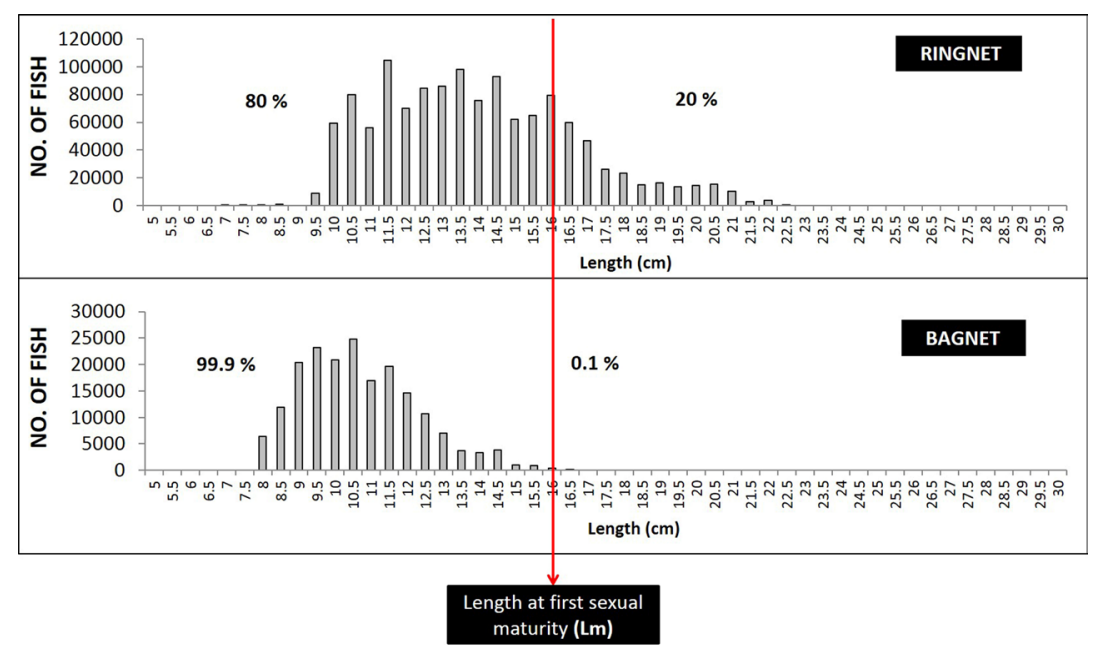

Figure 29. Length frequency distribution of Decapterus tabl (CY 2013, $\mathrm{Lm}=16 \mathrm{~cm}$ ).

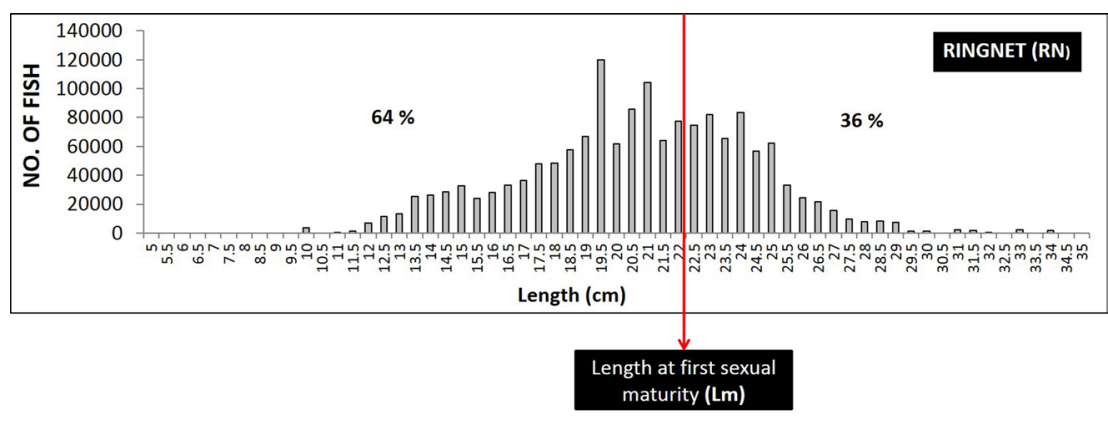

Figure 30. Length frequency distribution of Decapterus macarellus (CY 2013, $\mathrm{Lm}=22 \mathrm{~cm}$ ).

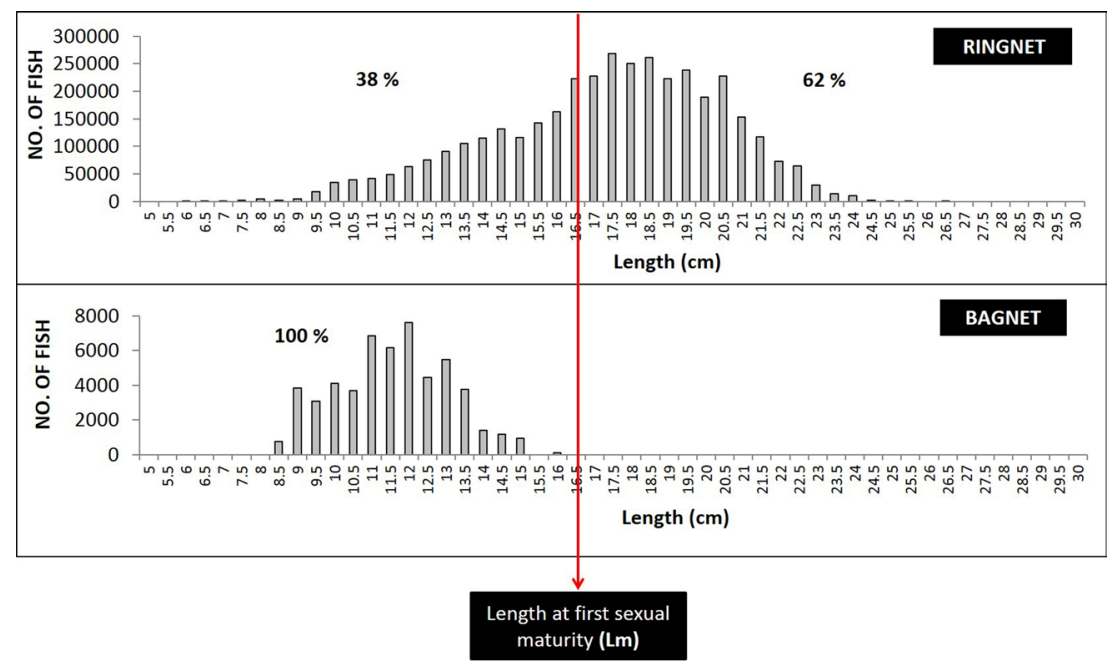

Figure 31. Length frequency distribution of Selar crumenophthalmus (CY 2013, $\mathrm{Lm}=16.5 \mathrm{~cm}$ ). 
being caught nowadays. $\mathrm{L}_{50}$ is the length at which $50 \%$ of the fish of that size are vulnerable to capture (Sparre 1987).

The $\mathrm{L}_{50}$ values computed from CY 2004 to 2013 showed that the fish species Auxis rochei, Mene maculata, Decapterus macarellus, Selar crumenopthalmus, Decapterus tabl, and Rastrelliger faughni caught by commercial fishing gears - ring net and bag net, have become smaller through time. The declining $\mathrm{L}_{50}$ values of the small pelagic fishes in Davao Gulf could be attributed to heavy fishing pressure employed in the fishing ground.

Figure 32 shows the fluctuating record of $\mathrm{L}_{50}$ of the species Auxis rochei. It ranged from $24.85 \mathrm{~cm}$ in 2004 and went down to about $18 \mathrm{~cm}$ in 2005 . After another year, it rose up to $21.67 \mathrm{~cm}$ then plunged back to $16 \mathrm{~cm}$ in 2007. It was in the year 2008 that the $\mathrm{L}_{50}$ of $A$. rochei started to gradually decrease from $23.15 \mathrm{~cm}$ up to its lowest length at $14.48 \mathrm{~cm}$ in 2013.

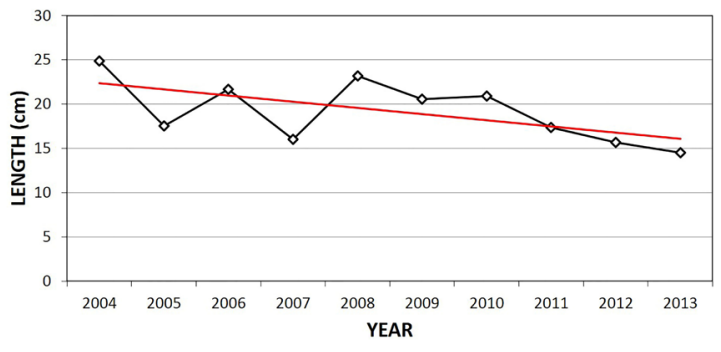

Figure 32. $\mathrm{L}_{50}$ of Auxis rochei (CY 2004-2013).

The length at first capture of other species such as Mene maculata in Figure 33 shows that the trend is behaving the same way as of $A$. rochei's $\mathrm{L}_{50}$. From 15.8 $\mathrm{cm}$ in 2004, it went down to $14.9 \mathrm{~cm}$ and $13.94 \mathrm{~cm}$ in 2005 and 2006 respectively. The $\mathrm{L}_{50}$ gradually decreased from time to time. It became $13.4 \mathrm{~cm}$ in $2007,12.94 \mathrm{~cm}$ in 2008 , and $13.13 \mathrm{~cm}$ in 2009 . It went up a notch in 2010 to almost $15 \mathrm{~cm}$ but after another year, it fell down to 13.3 $\mathrm{cm}$ and continued to decline to $11.7 \mathrm{~cm}-11.9 \mathrm{~cm}$ in 2013 and 2012 respectively.

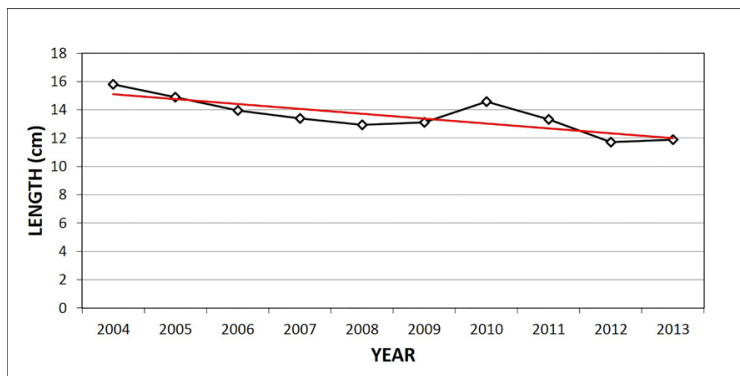

Figure 33. $\mathrm{L}_{50}$ of Mene maculata (CY 2004-2013).

The $\mathrm{L}_{50}$ of Decapterus macarellus was recorded at $24.21 \mathrm{~cm}$ in 2004 . However, it is considered to be $5.41 \mathrm{~cm}$ smaller when the $\mathrm{L}_{50}$ value documented in 2013 reached $18.8 \mathrm{~cm}$. The decline in L50 values of D. macarellus is presented in Figure 34. Likewise, Selar crumenophthalmus followed the same trend of the other species. In 2004, $\mathrm{L}_{50}$ of $S$. crumenophthalmus was $19.92 \mathrm{~cm}$ but went down to $16.82 \mathrm{~cm}$ in 2005. In the following year, $\mathrm{L}_{50}$ reached 23 $\mathrm{cm}$. It is evident that $\mathrm{L}_{50}$ of this species did not go higher than $20 \mathrm{~cm}$ until it went down to its lowest length in 2013 at $16.64 \mathrm{~cm}$.

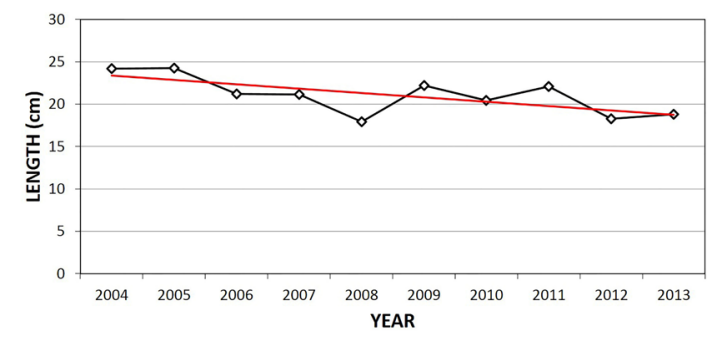

Figure 34. $\mathrm{L}_{50}$ of Decapterus macarellus (CY 2004-2013).

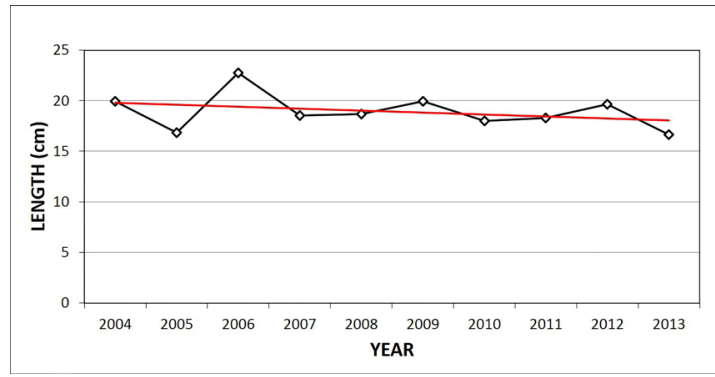

Figure 35. $\mathrm{L}_{50}$ of Selar crumenophthalmus (CY 2004-2013).

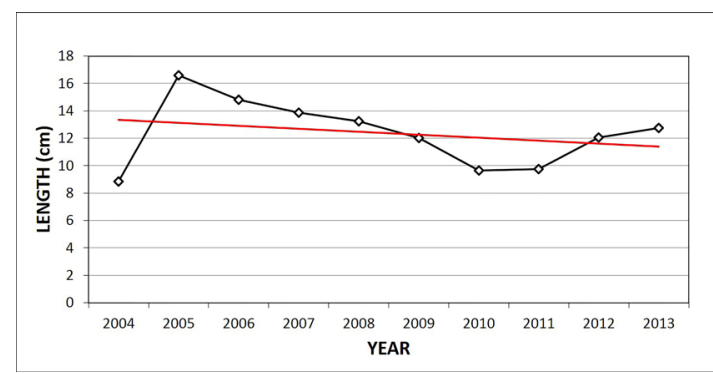

Figure 36. $\mathrm{L}_{50}$ of Rastrelliger faughni (CY 2004-2013).

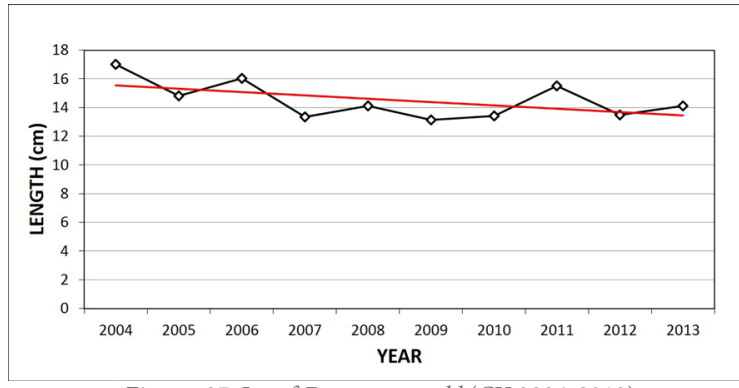

Figure. 37. $\mathrm{L}_{50}$ of Decapterus tabl (CY 2004-2013).

Moreover, Rastrelliger faughni was recorded to have the lowest $\mathrm{L}_{50}$ at $8.83 \mathrm{~cm}$ in 2004 . It suddenly increased to $16.6 \mathrm{~cm}$ in $2005 ; 14.82 \mathrm{~cm}$ in $2006 ; 13.87 \mathrm{~cm}$ in 2007; $13.23 \mathrm{~cm}$ in 2008; and $12.03 \mathrm{~cm}$ in 2009 . The $\mathrm{L}_{50}$ data of R. faughni showed a decrease from 2005 to 2010. 
In both 2010 and 2011, $\mathrm{L}_{50}$ values declined to $9.66 \mathrm{~cm}$ and $9.74 \mathrm{~cm}$ respectively, a little higher than the length recorded in 2004. Again, it climbed up to $12.05 \mathrm{~cm}$ in 2012 and $12.75 \mathrm{~cm}$ in 2013 . Figure 36 shows that $\mathrm{L}_{50}$ of $R$. faughni generally declined despite fluctuations observed in several years. The trend also showed a decreasing pattern in Decapterus tabl (Figure 37). The year 2004 recorded the longest $\mathrm{L}_{50}$ of $17 \mathrm{~cm}$. The values dropped constantly every year until it reached $14.12 \mathrm{~cm}$ in 2013 .

Table 2 shows the average $\mathrm{L}_{50}$ of the dominant small pelagic fishes in Davao Gulf with their corresponding $\mathrm{Lm}$. The data showed that majority of the population of these small pelagic fishes has been harvested before reaching the first sexual maturity stage except for Selar crumenophthalmus. This species may possibly migrated vertically in the water column for there were recorded instances of catch by gears targeting bottom dweller species (i.e. bottom set long line). This can be one of the many reasons why this fish survives the high fishing pressure even with exploitation values that ranged from $\mathrm{E}=0.54-0.86$. Without management measures implemented, there are possibilities that Selar crumenophthalmus and other small pelagic fishes can no longer withstand the extreme condition of fishing above the optimum level.

\section{Exploitation Values}

The exploitation rate is calculated using the formula $\mathrm{E}=\mathrm{F} / \mathrm{M}+\mathrm{N}$ or $\mathrm{E}=\mathrm{F} / \mathrm{Z}$. The standard value is $\mathrm{E}=0.5$ and is the threshold of exploitation. Exceeding this level is considered overexploitation of the stocks beyond the optimum yield.

Based on the results of the study, the over-all E-values of the following species Auxis rochei (Figure 38), Mene maculata (Figure 39), Rastrelliger faughni (Figure 40), Decapterus tabl (Figure 41), Decapterus macarellus (Figure 42), and Selar crumenophthalmus (Figure 43) exceeded the optimum level of exploitation. Hence, these small pelagic species are considered to be in a state of overexploitation. Although some species like R. faughni and $D$. tabl did not go beyond the threshold every year, the average E-values of these species already surpassed the limit. Accordingly, the top six small pelagic species exhibited high E-values ranging from 0.51-0.86. This may indicate that overfishing has been occurring in Davao Gulf for more than a few years.

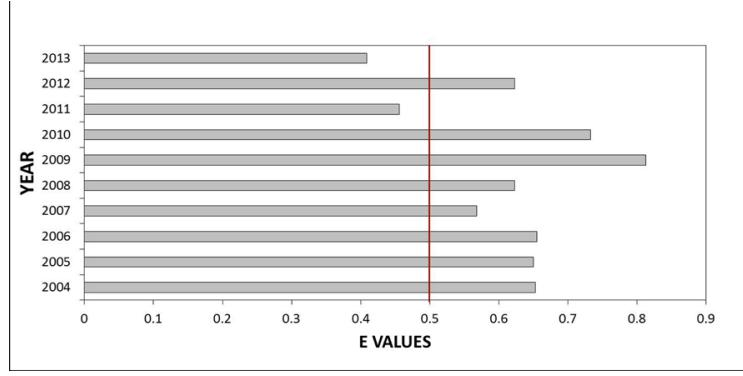

Figure 38. Exploitation values of Auxis rochei (CY 2004-2013).

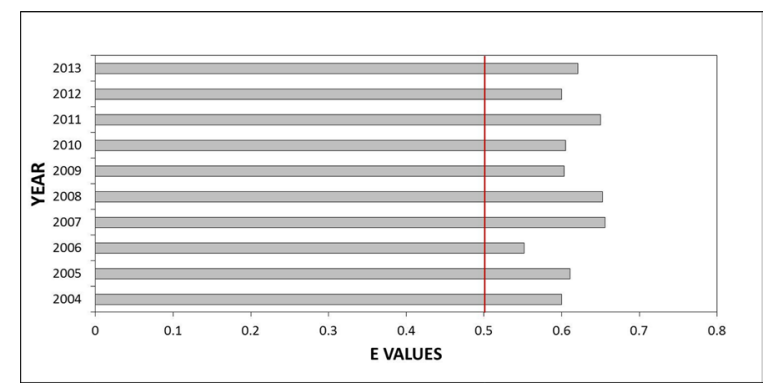

Figure 39. Exploitation values of Mene maculata (CY 2004-2013).

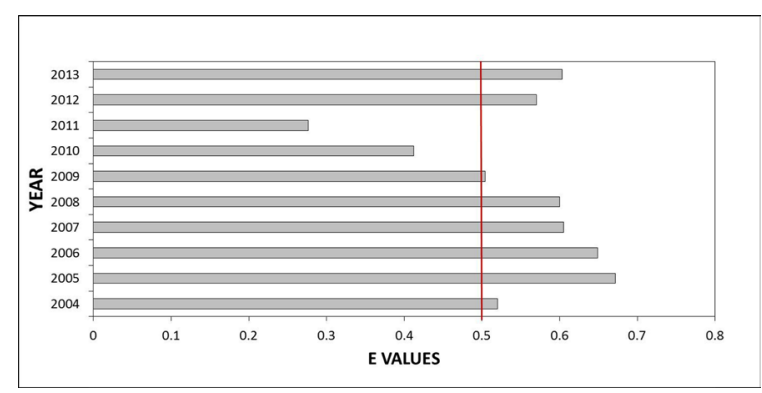

Figure 40. Exploitation values of Rastrelliger faughni (CY 2004-2013).

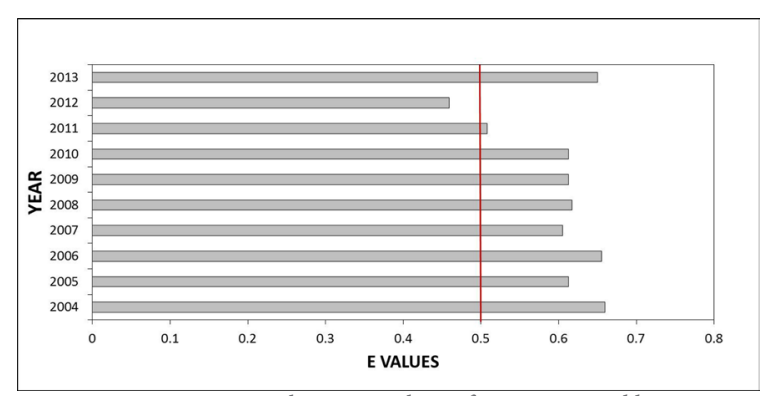

Figure 41. Exploitation values of Decapterus tabl (CY 2004-2013).

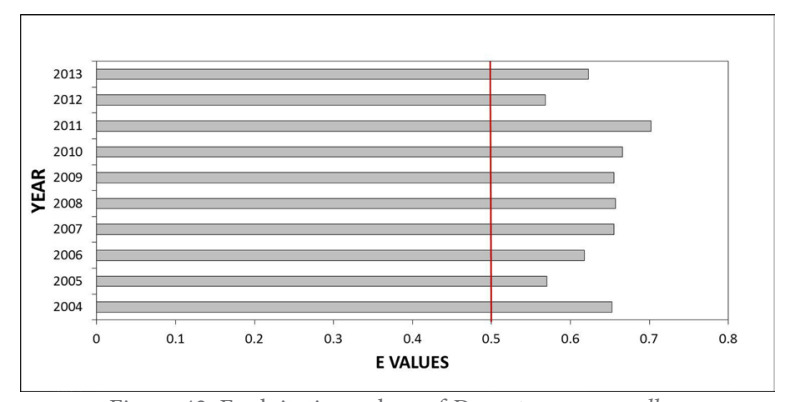

Figure 42. Exploitation values of Decapterus macarellus

(CY 2004-2013)

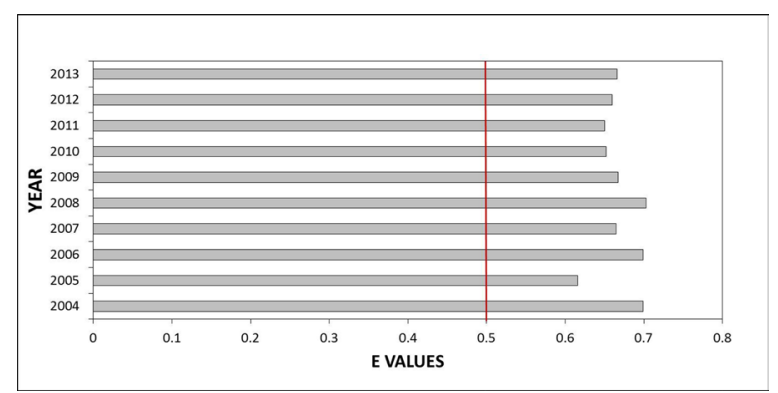

Figure 43. Exploitation values of Selar crumenophthalmus (CY 2004-2013). 


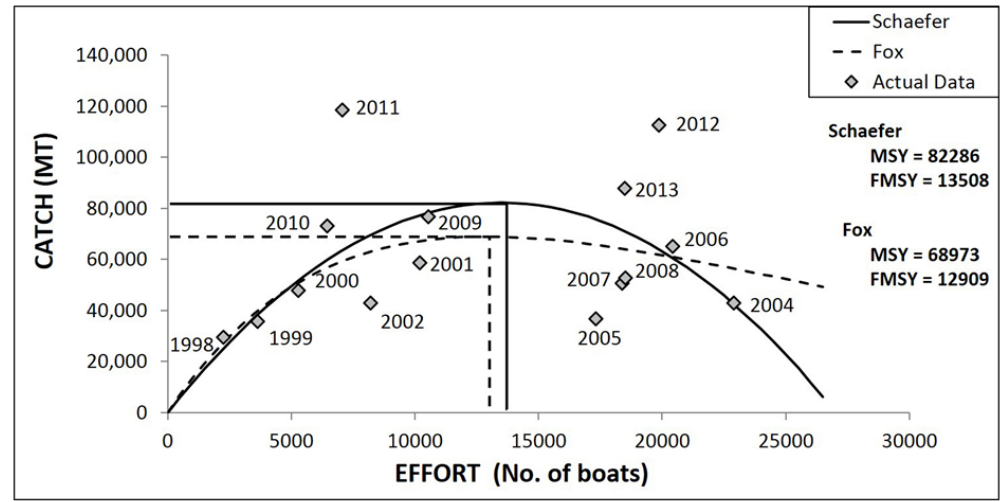

Figure 44. Maximum potential yield (MPY) estimates of Davao Gulf (CY 1998-2013).

\section{Surplus Production Model (Potential Yield)}

The potential yield (PY) of Davao Gulf from 1998-2013 was estimated using the Schaefer and Fox models. The values obtained for the maximum yield were 82,286 MT and 68,973 MT for Schaefer's and Fox's models respectively. While the optimum efforts recorded were 13,508 and 12,909 landed boats. Figure 44 shows the annual data of the yield plotted against the total annual effort. The values recorded from 1998 to 2001 were below the level of the MPY estimates of both models. However, starting 2004 up to 2008, the total production and the effort have already reached and exceeded the allowable limit which resulted to the declining catch and CPUE. An evident slight recovery was noticed in 2009 and 2010 where the values bounced back below the potential yield estimate of Schaefer's model. This occurrence may perhaps paved way for the max out production in 2011. Furthermore, exploitation level again escalated as the number of landed boats build up after 2011 causing the yield to dwindle in the next two years, 2012-2013. The results strongly suggest that Davao Gulf has already reached and exceeded its MPY. The total production will possibly continue to decline if unsustainable fishing practices will be exerted in the succeeding years. This instances might lead to the depletion of the fishery resources in Davao Gulf such as the small pelagic fishes.

\section{S UMM A R Y}

The data gathered from CY 2004-2013 showed that commercial fishing having an annual average catch percentage of $88 \%$ dominated the fishing activities around Davao Gulf compared to municipal fishing which only comprised $12 \%$ of the average catch in ten years. There were 27 types of fishing gears operating in Davao Gulf. Out of these 27 fishing gears, only two fishing gears were commercial. Commercial fishing gears are the ring net and the bag net. These two commercial fishing gears contributed largely to the total production in Davao Gulf.

The catch per unit effort trend of ring net both in payao and free school and bag net was decreasing. The ring net in payao has an average annual catch of
3,069.62 MT/year dominated by Selar crumenophthalmus comprising $32 \%$ of the catch. The ring net in free school has an annual average catch of 199.25 MT/year having Mene maculata as the dominant catch of $41 \%$. Moreover, the species Auxis rochei dominated the catch of bag net with an average catch of $122.21 \mathrm{MT} /$ year. Annual average catch of these two commercial fishing gears decreased from 2004 to 2013.

The catch of Auxis rochei and Mene maculata declined from $44 \%$ and $83 \%$ respectively from 2004 to 2013. On the other hand, the annual catch of Selar crumenophthalmus, Decapterus macarellus, D. tabl and Rastrelliger faughni have increased. The relative abundance of fish species and families recorded has also declined.

Based on the time series data, the length frequency distribution of the six selected commercially important small pelagic fishes caught by commercial fishing gears (ring net and bag net) in Davao Gulf showed to have been caught in much smaller sizes compared to the sizes of fish caught several years way back. Almost ninety percent $(90 \%)$ of small pelagic fishes which are still immature was caught by the use of bag net due to the gear's fine mesh net.

The over-all exploitation values of the species have already exceeded the optimum value of $E=0.5$. Also, the potential yield of Davao Gulf showed that the total production and effort have already reached and exceeded the allowable limit based on the estimates provided by both Schaefer's and Fox's models in the MPY.

Extraction of stocks before they reached their maturity may implicate growth and recruitment overfishing. The commercial gears in Davao Gulf which supply the largest bulk of small pelagic fish catch in the region were confirmed to have caught immature fishes. The juveniles are vulnerable to fishing mortality. Harvesting of small pelagic fishes at this stage can deter the growth of these stocks. This would not give them the chance to reach their sexual maturity stage in order for them to spawn and reproduce. Therefore, Davao Gulf must be managed and conserved to let the stocks replenish and enter the fishery as new recruits. 


\section{R E C OMMEN DAT I O N}

Based on the study's results, the following are recommended:

1. Conduct information dissemination (lectures) on the status of Davao Gulf using BFAR XI - NSAP scientific data results and findings.

2. The use of commercial gears must be regulated and banned during spawning season of small pelagic fishes in Davao Gulf; encourage the operators to fish and explore other fishing grounds on the East Coast side.

3. The use of fine mesh net shall be banned in Davao Gulf; a minimum of $3 \mathrm{~cm}$ or 10 knots mesh size in all parts of the fishing gear specifically on the bunt/bag portion is recommended.

4. Regulate the construction of new commercial fishing vessels to control the fishing effort.

5. The entire Davao Gulf shall be put into a conservation and management area and shall adapt an integrated ecosystem approach as a management tool.

6. Formulate Joint Administrative Orders in the implementation of management measures.

7. To encourage the Local Government Units to adopt a standard city/municipality integrated fishery ordinances among coastal cities and municipalities in Davao Gulf.

\section{ACKNOWLED GEMEN T}

This is to acknowledge the following persons who in one way or another helped to make this manuscript come into a reality:

To our Regional Director, Ms. Fatma M. Idris, CESO V, for the support given to the National Stock Assessment Program in Region XI;

To our mentors, Mr. Nygiel. B Armada, Mr. Geronimo P. Silvestre, Dr. Jose A. Ingles, Felimon C. Gayanilo Jr., Dr. Wilfredo Campos, for their painstaking effort in molding the author in acquiring advance knowledge on fish stock assessment and for the critics on the data analyses using FiSat routines and other assistance during the program implementation in Region XI;

To Ms. Ethel G. Llana, Scientist II, for editing this manuscript;

To Mr. Noel C. Barut, as the "Father" of the National Stock Assessment Program and for institutionalizing the implementation at BFAR regional level, as well as for the training, support, and assistance to the NSAP Project Leaders nationwide;

To Dr. Mudjekeewis D. Santos and Mr. Francisco S.B. Torres for the help extended during the inception of the draft of this manuscript;

To Ms. Daisy C. Burgos, Assistant Project Leader, for the help in the preparation of this paper;

To all NSAP technical data collectors for their patience in data gathering and for serving as the forefront in the collection of the important information for.
Without the NSAP data collectors, this paper would not be possible;

To all NSAP data analysts for encoding and providing the processed report generations;

To my BFAR colleagues, thank you for your support; and

To our Divine Almighty, for providing the strength during the ups and downs on the implementation of this project.

\section{R E F E R E N C E S}

Armada NB.. 2002. Fishery resources assessment of Davao Gulf, Philippines. Resource and Social Assessment of Davao Gulf, Philippines. University of the Philippines Visayas, Miagao, Iloilo.

Barut NC, Santos MD, Garces LR. 2004. Overview of the Philippine marine fisheries, p. 22-31. In DA-BFAR (Department of Agriculture-Bureau of Fisheries and Aquatic Resources). In turbulent seas: The status of Philippine marine fisheries. Coastal Resource Management Project, Cebu City, Philippines. p. 378.

Beverton RJH, Holt SJ. 1956. A review of methods for estimating mortality rates in exploited fish populations, with special reference to sources of bias in catch sampling. Rapp. P.-v. Reun. CIEM 140: 67-83.

Corpuz AJ, Saeger J, Sambilay V. 1985. Population parameters of commercially important fishes in Philippine waters. Tech. Pap., UPV Dept. Mar. Fish. 6: 99.

Dalzell P. 1988. Small pelagic fisheries investigation in the Philippines. Part II. The current status. Fishbyte 6(3): 2-4.

Dalzell, P. and G. Penaflor. 1989. The fisheries biology of the big eye scad, Selar crumenopthalmus (Bloch), in the Philippines. Asian Fisheries Science 3: 115-131.

Dalzell P, Ganaden RA. 1987. A review of the fisheries for small pelagic fishes in Philippine waters. Tech. Pap. Ser., Bureau of Fisheries and Aquatic Resources (BFAR) 10(1): 58 p. BFAR, Quezon City, Philippines.

Dwiponggo A, Hariati T, Banon S, Palomares ML, Pauly D. 1986. Growth, mortality and recruitment of commercially important fishes and penaeid shrimps in Indonesian waters. ICLARM Tech. Pap. 17. p. 91

Dy-Ali E. 1988. Growth, mortality, recruitment and exploitation rate of Selar boops in Davao Gulf, Philippines. FAO Fish. Rep. 389: 346-355

FAO (Food and Agriculture Organization of the United Nations). Guidelines for the routine collection of capture fishery data. Prepared at the FAO/DANIDA 
Expert Consultation. Bangkok, Thailand, 18-30 May 1998. FAO Fisheries Technical Paper. No. 382. Rome, FAO. 1999. p. 113.

Froese R, Pauly D, editors. 1998. FishBase 4B: Concepts, Designs and Data Devices. ICLARM, Manila, Philippines. p. 293.

Ganaden SR, Ali ED. 1992. Unpublished. The Ring Net Fishery of Davao Gulf.

Gayanilo FC Jr, Sparre P, Pauly D. 1996. FAO-ICLARM Stock Assessment Tools (FISAT), User's Manual. FAO Comp. Info. Ser. (Fisheries) 8: 126.

Gonzales FL. 1991. Growth, mortality and recruitment of Decapterus kurroides in Davao Gulf, Philippines.

Gulland JA. 1969. Manual of methods for fish stock assessment. Part 1. Fish population analysis. 99-103, pp. $58-74$.

Gulland JA. 1983. Fish Stock Assessment: A Manual of Basic Methods. Chishester, U.K., Wiley Interscience, FAO/Wiley Series of Food and Agriculture, Vol. 1: 223.

Gulland S. 1971. The Fish Resources of the Oceans. FAO/ Fishing News Books Ltd., Surrey, England.

Haddon M. 2001. Modelling and quantitative methods in fisheries. Chapman \& Hall/CRC. United States of America.

Ingles J, Pauly D. 1984. An atlas of the growth mortality and recruitment of the Philippine fishes. ICLARM Tech.l Pap. 13. ICLARM, Manila, Philippines. p. 127.

Lavapie-Gonzales F. 1991. Growth, mortality and recruitment of Decapterus kurroides in Davao Gulf, Philippines. Fishbyte 9(2): 6-9.

Lavapie-Gonzales F, Ganaden SR, Gayanilo FC Jr. 1997. Some population parameters of commercially important fishes in the Philippines. BFAR, Quezon City, Philippines. p. 114.

Mindanao State University. 1995. Rapid resource appraisal project of Davao Gulf.

Pauly D. 1978. A preliminary compilation of fish length growth parameters. Ber. Inst. Meereskd. ChristianAlbrechts-Univ. Kiel (55): 1-200.

Pauly D. 1980. On the interrelationships between natural mortality, growth parameters, and mean environmental temperature in 175 fish stocks. J. Const. Int. Explor. Mer 39(2): 175-192.

Pauly D. 1984. Fish population dynamics in tropical waters: a manual for use with programmable calculators. ICLARM Studies and Reviews 8: 325.

Pauly D, Navaluna NA. 1983. Moonsoon-induced seasonality in the recruitment of Philippines fishes. FAO Fish. Rep. 3(291): 823-833.

Pauly D, David N. 1981. ELEFAN I: a basic program for the objective extraction of growth parameters from length-frequency data. Meeresforsch/ Reports on Marine Research 28(4): 205-211.

Pauly D, Munro JL. 1984. Once more on the comparison of growth in fish and invertebrates. Fishbyte 2(1): 21.

Powell, DG. 1979. Estimation of mortality and growth parameters from the length-frequency in the catch. Rapp. P.-V. Reun. CIEM, 175: 167-169.

Resource and Social Assessment (RSA) of Davao Gulf, Philippines. 2002. Part II: Social and Economic Assessment (SEA). University of the Philippines in the Visayas Foundation, Inc. U.P. in the Visayas. Miagao, Iloilo.

Republic Act 8550. 1998. The Philippine Fisheries Code of 1998.

Rivera P. 2002. Climatology and oceanography of Davao Gulf, Philippines. Resource and Social Assessment of Davao Gulf, Philippines. University of the Philippines Visayas, Miagao, Iloilo.

Romena N, Villanueva J. 2002. GIS Application on capture fisheries in Davao Gulf. Presented on NSAP Year-end review. Manila, Philippines. Unpublished manuscript.

Ronquillo IA. 1975. A review of the roundscad fishery in the Philippines. Philipp. J. Fish. 11(1\&2): 87-126.

Ronquillo IA, Cabral-Llana ME. 1985. A bibliography of BFAR's researches and popular writings (19471984). Bureau of Fisheries and Aquatic Resources Tech. Paper Ser. 8(1): 104.

Ruangsivakul N, Prajakjitt P, Dickson JO, Siriraksophon S. 2003. Fishing gear and methods in southeast asia: III. Philippines, Part 1. Southeast Asian Fisheries Development, Training Department. PO. Box 97, Phrasamutchedi, Samutprakan 10290, Thailand.

Schaefer MB. 1954. Some aspects of the dynamics of populations important to the management of the commercial marine fisheries. Inter-Am. Trop. Tuna Comm., Bull. 1(2): 27-56.

Silvestre GT, Soriano ML, Pauly D. 1991. Sigmoid selection and the Beverton and Holt yield equation. 
Asian Fish. Sci. 4: 85-98.

Sparre, P. 1987. Computer programs for fish stock assessment. Length-based fish stock assessment for Apple II computers. FAO Fish Tech. Pap., (101) Suppl. 2:218.

Sparre P, Venema SC. 1992. Introduction to tropical fish stock assessment. Part I. Manual. FAO Fish. Tech. Pap. No. 306.1, rev. 1. FAO, Rome. p. 376.

Tandog-Edralin D, Ganaden SR, FoxP. 1988. A comparative study of fish mortality rates in moderately and heavily fished areas of the Philippines. In: S. C. Venema, J. Moller Christensen and D. Pauly (eds.), Contribution to Tropical Fisheries Biology: papers by the participants at the FAO/DANIDA Follow-up Training Courses on Fish Stock Assessment in the Tropics, Denmark, 1986 and Philippines, 1987. FAO Fish. Rep. 389: 519.

Wetherall JA. 1986. A new method for estimating growth and mortality parameters from length-frequency data. ICLARM Fishbyte 4(1): 12-14. 